University of Louisville

ThinkIR: The University of Louisville's Institutional Repository

Electronic Theses and Dissertations

$5-2010$

\title{
The changing discourse of death : a study of the evolution of the contemporary funeral industry.
}

Lisa Suzanne Crabtree 1980-

University of Louisville

Follow this and additional works at: https://ir.library.louisville.edu/etd

\section{Recommended Citation}

Crabtree, Lisa Suzanne 1980-, "The changing discourse of death : a study of the evolution of the contemporary funeral industry." (2010). Electronic Theses and Dissertations. Paper 286.

https://doi.org/10.18297/etd/286

This Master's Thesis is brought to you for free and open access by ThinkIR: The University of Louisville's Institutional Repository. It has been accepted for inclusion in Electronic Theses and Dissertations by an authorized administrator of ThinkIR: The University of Louisville's Institutional Repository. This title appears here courtesy of the author, who has retained all other copyrights. For more information, please contact thinkir@louisville.edu. 
THE CHANGING DISCOURSE OF DEATH: A STUDY OF THE

\title{
EVOLUTION OF THE CONTEMPORARY FUNERAL INDUSTRY
}

\author{
By \\ Lisa Suzanne Crabtree \\ B.A., Bellarmine University, 2003

\begin{abstract}
A Thesis
Submitted to the Faculty of the

College of Arts and Sciences of the University of Louisville in Partial Fulfillment of the Requirements

for the Degree of
\end{abstract}

Master of Arts

Department of Sociology

University of Louisville

Louisville, Kentucky

May 2010 
Copyright 2010 by Lisa Suzanne Crabtree

All rights reserved 


\section{THE CHANGING DISCOURSE OF DEATH: A STUDY OF THE EVOLUTION OF THE CONTEMPORARY FUNERAL INDUSTRY \\ By \\ Lisa Suzanne Crabtree \\ B.A., Bellarmine University, 2003}

Thesis Approved on

April 8, 2010

by the following Thesis Committee:

Thes/s Director 


\section{DEDICATION}

This thesis is dedicated to my late sister

Kristine Marie Kauffmann

for somehow instilling peace in my heart during our one-sided middle-of-the-night talks. 


\section{ACKNOWLEDGMENTS}

I would like to thank my thesis advisor, Dr. Allen Furr, for his patience, understanding, and consistent encouragement; also my committee members Dr. John Ferre' and Dr. Melissa Evans-Andris for their guidance and support. Without the opportunities provided by my exceptionally hard-working parents, Susan and Michael Kauffmann, I would not be where I am today. I am deeply indebted to my friends Kimberly Kasey, Brittany Inge and Dr. Benjamin Birkby for their invaluable input and contributions. I would be remiss not to mention Brian Easterling, librarian at the Cincinnati College of Mortuary Science, whose generosity and assistance made this research possible. Finally, I want to thank my husband, Kyle Crabtree, for his gentle nature, incredible intellect, and willingness to exchange ideas and act as a sounding board throughout this process, and always. 


\begin{abstract}
THE CHANGING DISCOURSE OF DEATH: A STUDY OF THE EVOLUTION OF THE CONTEMPORARY FUNERAL INDUSTRY

Lisa Suzanne Crabtree
\end{abstract}

April 8, 2010

Within a cultural context of postmodernism and individualization, funerals in America have taken on a new appearance amidst increased freedom of expression and diminished adherence to tradition. This thesis examines how the funeral industry has evolved along with these social and cultural changes. Articles randomly selected from a leading funeral industry trade journal, Mortuary Management, are explored utilizing a combined quantitative content and qualitative textual analysis approach. Examination of selected articles (1963-2009) reveals that the funeral industry has steadily attempted to maintain sociocultural relevance through adaptation to a postmodern ethos of informalization and mercuriality. Possible mitigating factors for identified industry changes are discussed. 


\section{TABLE OF CONTENTS}

PAGE

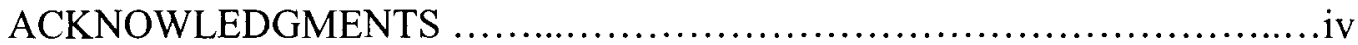

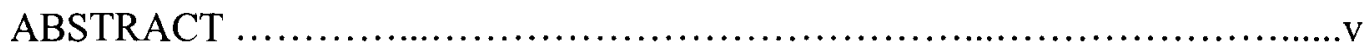

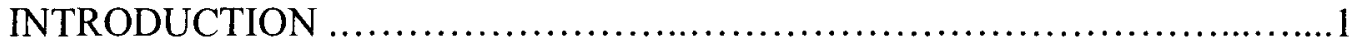

LITERATURE REVIEW AND THEORETICAL FRAMEWORK ................9

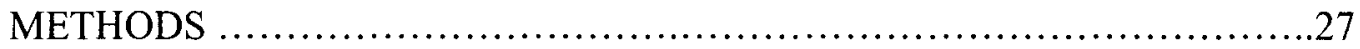

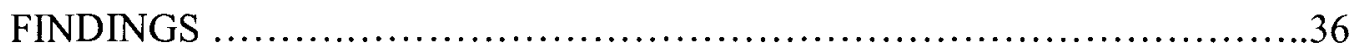

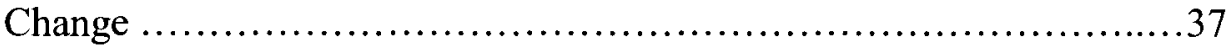

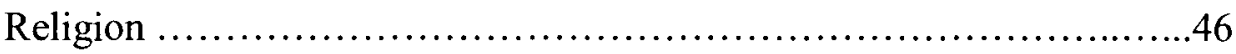

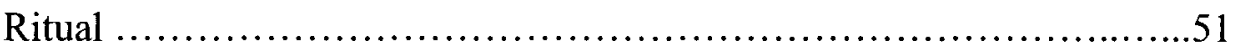

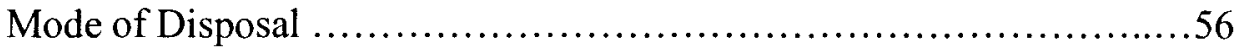

Image, Sustainability, and Commerce .................................62

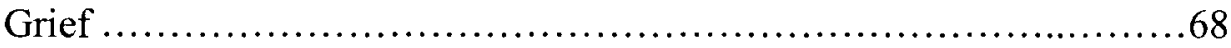

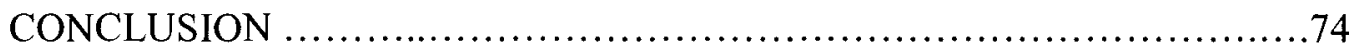

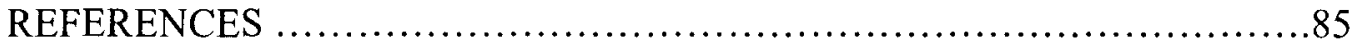

APPENDIX A: List of Analyzed Mortuary Management Articles ...............90

APPENDIX B: Content Analysis Instrument.................................95

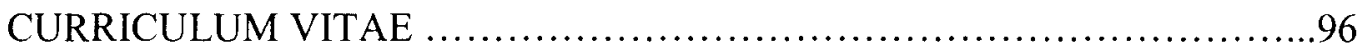




\section{CHAPTER I}

\section{INTRODUCTION}

It has been stated countless times that a country's treatment of its dead is a legitimate barometer for its collective value system. If we stop to consider our own country's sociohistorical biography within a backdrop of mortality, at some point we must wonder "when did a single death become so monumental?" The imprint of a death is culturally based, as is how we choose to signify its incidence. Even why we grieve who we grieve is affected by milieu; where variation become obvious lies primarily in the epoch. In other words, why parents mourn the death of their daughter in 2008 differs from why parents in 1908 mourned the death of their daughter.

As ways to die proliferate, so do ways to memorialize. The industrial implications of this postmodern emergence of endless options stimulate the construction and design of how we remember and how we want to be remembered. Our expectations have great influence on our choices. Individuals in contemporary society expect and demand ever more as accessibility to more things, ideas, people, and places is greater than any other point in history. One's community is no longer immediate, and so this provokes the innovation of new options for connecting with kinship at times of death. Presently, in order to 
perpetuate shared rituals and consequently sustain itself, the funeral industry is clamoring to assert its presence.

Today's funeral is not the funeral of a year ago, ten years ago, and certainly not fifty or a hundred years ago. The contemporary funeral is often chosen from a cafeteria-style presentation of what might loosely be termed "rituals"; along with the necessary accoutrement, and elected techniques for personalization, all aimed at "celebrating the uniqueness" of the deceased. Traditions of funerals past feel irrelevant in this increasingly secular, informal socalled "me generation" with an arrested attention span. Our ancestors commonly relied on the word "dignified" to describe a "good" death or a "good" funeral; today, emphasis is on a memorial service that "celebrates" life and satiates attendees' need to assure themselves that they properly represented the deceased. In summary, the notion of a funeral does not conjure the same image today that it did yesterday. [While maintaining an awareness of countless regional, ethnic, religious differences amongst funeral practices, for the purpose of this paper it is necessary to focus on a generalized notion of the American funeral industry.]

Contemporary options are many for how to conduct a service, yet many of those options have been manufactured in industry marketing sessions as ways to generate revenue. Funeral webcasts, jewelry fashioned from cremains, custom slideshows of the deceased's younger days, forays into the world of pet memorialization, and pre-planning services are all examples of recent industry attempts to maintain viability. Our postmodern self-obsessed temperament and inward foci dictates what rituals, feelings, honors, etc. we deem worthy of our 
time. How we grieve now makes perfect sense in light of what Beck refers to as the goal of "making one's life a work of art (2002:43)." He notes that it is "precisely this level of pre-conscious collective habitualizations of matters taken for granted that is breaking down into a cloud of possibilities to be thought about and negotiated." This idea, of course, hearkens back to Durkheim, anomie, and "the evil of missing boundaries ([1912] 2001)." A key distinction to note regarding the work of Durheim is his focus on emotions in a collective context.

The American funeral industry has either paved the way, or followed suit, depending on your perspective. The rising popularity of cremation, green burials, and home burials may simply be viewed as a response to the high costs of the accoutrements associated with a traditional funeral and burial. As the typical wake or viewing period has been reduced over time (Garces-Foley 2006), pre-need services are increasingly marketed, as these packages are an essential means for keeping businesses afloat in today's market. Due in large part to the corporate overhaul by companies like Service Corporation International (SCI), small, privately-owned funeral homes in existence for generations are a dying breed. Many Americans have remained unaware of this, due to the fact that in a rather savvy business move, when SCI (or similar others) purchases these establishments, they also purchase name-rights and maintain the name in an effort to rely on an established reputation.

Further, unlike many traditional funeral-related tasks which, according to law promulgated by the Federal Trade Commission, only a licensed funeral director could perform, there is little need for the services of a professional in 
some contemporary trends. In other new arenas, the services of a funeral director are entirely obsolete. It is inarguably a different era from the days of full reliance on a professional to guide a family through the entire decision-making process. Funeral homes must compensate for fewer clients as people turn to any of the number of the current options for memorialization that do not involve the services of an industrialized funeral home. For example, as we are beginning to see a return to simplicity and self-sufficiency in other realms of modern American life, we are simultaneously seeing a minor revival of primitive death and funeral rituals. A July 2009 New York Times article (Zezima 2009) detailed the "natural burial movement" and notes a steady increase in home burials. According to that article, in 2002, only two organizations devoted to helping families with the process of home burials existed; today, there are 45. Compared to the average American industry-run funeral and burial at $\$ 6000$, a home burial is considerably cheaper at $\$ 300$.

The funeral industry is no different than any other industry, and this is particularly true in the postmodern era of reinvention. While it is unlikely that the funeral industry will ever be wholly obsolete, it certainly is not sustainable in its current incarnation. An industry that once cornered the market has been forced to adapt, in many cases completely reinvent itself, and fall at the feet of consumer choice and whim. The industry cannot control the number of deaths or number of funerals, but it can attempt to control the presentation of deaths; hoping to persuade the soon-to-die that their unique life will be best represented by their handling of the death. 
An American mindset having a historically positive impact on the funeral industry was the emblematic relationship between strength and depth of love for the deceased and elaborateness of memorialization. This has been conveyed through casket choice, an ornate monument, or an indestructible vault; in other words, the preciousness of the vessel had to match preciousness of its contents. This notion has in many ways persisted. For those following the traditional burial route, there is yet a tendency for families to purchase the best funeral items they can afford (or sometimes cannot afford). That is, for some, a relationship appears to exist between how much we love our deceased and how much we spend on their casket. Recently, American media latched on to the fact that Michael Jackson's casket was a gold-plated model valued at $\$ 50,000$. His televised memorial broke network records for viewership (Archibold 2009; Itzkoff 2009; Stanley 2009). Choreographed with the precision of a timeless event, the highly personalized service was deemed important enough to drive further into debt a city already struggling in a time of recession. Recent reports have revealed that Jackson's hair will be turned into diamonds (Black 2009). According to Marx, "The more alienated [man] is, the more the sense of having and using constitutes his relationship to the world ([1845] 1978)." Logic would seem to dictate then, that there also exists a positive correlation between having and displaying; and to extend a connection to the topic of memorialization, between the grandeur and personalization of funeral rituals and the extent of our grief.

Social status has long been proclaimed by elaborateness of weddings and funerals; however, it is a relatively new phenomenon that these rituals also 
communicate our personality traits, social values, treasured pastimes, and sense of aesthetics. Although such conspicuous consumption has been present in the death rituals of various cultures for centuries, Cook \& Walter (2005) attribute the 1997 funeral of Diana Princess of Wales to beginning a similar trend of personalization among British funerals. In many ways, funeral ceremonies have become "proving grounds." The belief that the peace, happiness and/or salvation of the dead depends on the "correct" funeral rites is now emphasized more than ever. The pressure is on to emphasize the uniqueness, goodness, and rarity of the deceased; almost as if the universe will hear, and based on this information, establish a special spot for his/her soul in eternity (a spot that was formerly, of course, reserved by way of religious devotion).

When planning a contemporary event, money is essentially the only limitation. Searching for "meaning," once a part of life fulfilled by attending church on Sundays, has for many been replaced by a daily secular search. Historically, a funeral was an expected means to an end, a signing off and a giving back to the earth. Now funerals are marketed as and designed to be an opportunity to show who you are and what a special life you lead. It is a celebratory goodbye, as opposed to a "home-going" ceremony. Then, the industry made appeals to piety, familiarity, and religiosity. Now, appeals are made to our wallet and our vanity.

A decline in adherence to religious convention is contributing to the funeral practice and industry metamorphosis. The reality is that all of our once sacrosanct rituals are changing in the postmodern era. Where we once relied on 
scripture readings to dictate the order and meaning of weddings and funerals alike, the increasing secularization of American society has resulted in a gap to be filled. We are in the nascent stages of an "anything goes" era of ceremony. Cook $\&$ Walter (2005: 366) found that "even in contexts where the religious faith of those attending is both strong and homogeneous, there are likely to be significant differences from the past." Historically it was taken for granted that funeral services were religious, anything otherwise would have been highly unusual. Religious convictions dictated how we understood death, approached it, and knew how to care for the deceased, where they were going, if we could plan on joining them, etc. Now we see an amalgamation of rituals -- some invented, some borrowed from foreign creeds, some familiar approaches from the faith of one's upbringing.

Paradoxically, while Americans are entertaining themselves with representations of death in popular culture, they are increasingly obsessed with prolonging life as long as possible. Foltyn (2008) believes that now more than ever, humans are fascinated with the dead body. As people are both afraid of and transfixed by death, television shows detailing the industry (e.g., Six Feet Under) are highly successful. Due in part to widespread popular-culture exposure to death, violence, disaster, and terrorism, both real and imagined, he identifies the paradox of the American corpse, noting that we are "ambivalent about the status of the corpse, displaying it and hiding it, revering and defiling it, viewing it as useful and useless and a source of amusement and somberness" (2008: 100). Such 
ambivalence has inevitably extended to trends in consumer desires, and consequently, funeral industry service offerings.

Proceeding from the evidenced postmodern American ideal positing that our "death-style" should match our "life-style," this paper explores the recent (post-1963) transformation of the American funeral industry in order to lay a framework for discussion of contemporary issues and put current practices in context. Specifically, it considers the questions: 1) What themes emerge from content and textual analysis of the funeral industry trade journal Mortuary Management? 2) How did the focus of the industry shift on the specific chosen domains? and, 3) What does trade journal content indicate as possible mitigating factors in industry change? A content and textual analysis spanning five decades [1960-2009] of the widely circulated funeral industry trade journal Mortuary Management serves as an evidence base for changing attitudes and practices. 


\section{CHAPTER II}

\section{LITERATURE REVIEW}

Evidence of a dearth of publications specifically contemplating the industrial aspects of death, a Sociological Abstracts search of the phrase "funeral industry" results in only four pages of thirty-two hits, the majority of which focus on the state of the industry in Japan, the UK, and Botswana. What might be considered some of the most germane and timely on-topic information regarding the American funeral industry has been published in recent issues of the New York Times (e.g., see Archibold 2009; Glaser 2009; Zezima 2009). These newspaper articles alternately highlight current industry rhetoric, elucidate emerging trends, and cite relevant statistics, placing the topics in a cultural and socioeconomic context that lends itself well to social research.

Current scholarly literature on death tends to focus on changing funeral rituals, and exploring how society perceives death in light of those rituals. Additionally, research has concentrated on the changing ways in which Americans view death and the implications of the transition from a communitybased to individual-based society for the world of death and funeral work. Change in value systems alongside this systemic socio-cultural revaluation has resulted in what Lynch (2004:14) terms "customized send offs." One study from Torres 
(1988) undertook a content analysis of industry journals, though the funeral industry and funeral directors were utilized as illustrative of the process of professionalization. The authors provided a lengthy and detailed description of the industry, but there was no attempt at sociological analysis of the industry practices, or commentary on the evident changes in offerings or attitude.

It appears that most concentrated research on death is currently taking place in Great Britian (see Exley's 2004 review of recent British scholarly death literature). Briton Tony Walter is arguably the most prolific contemporary scholar on the topic of death and dying. His 2005 study of religious, ethnic and countryspecific death practices offers a comparative analysis of funeral variation across countries in the western world. Other writings focus on the linguistic changes in funeral rites and the conceptualization of three types of historical deaths.

Some previous research has documented the evolution of the American funeral, some has focused on the contemporary American funeral, and a very small portion has focused on the funeral industry itself. Evidence has previously been gathered through funeral attendance, interviews with clergy and industry professionals, and otherwise largely anecdotal evidence. There has been popculture discussion of death's evolution and academic consideration of its implications; however, no previous study has undertaken a comprehensive content analysis of a funeral industry trade journal in order to document the changes.

Since its Civil War era inception, the professionalized American funeral industry has contributed to the shaping of death rites. As descriptive background, 
Winkel (2001) discusses how the process of mourning was "constructed" in the $19^{\text {th }}$ century, while Garces-Foley and Holcomb (2006) provide a concise summary of contemporary American funeral practices. In keeping with the specialization found in most aspects of American life (e.g. the rise of professions), Troyer (2007) discusses the history of embalming and its immeasurable contribution to the industrialization of death practices. Prior to the popularization of embalming, in a community-based society, family members were familiar with the decomposition process and required swiftness for preparation of the body. Families were directly involved in washing and dressing the body, rearranging the parlour furniture to accommodate the corpse for viewing, and hosting a wake. As embalming became socially normalized, death care and funeral responsibilities shifted from family to the domain of a professional mortician.

Embalming made death seem almost magical. Because families now trusted their loved one's remains to a group of unfamiliar professionals, they lost that intimate knowledge of the natural consequences of death. The current psychological argument hinges on the necessity of seeing the body "one last time" and the importance of a last viewing for acceptance and healing (Howarth and Leman 2001). Undoubtedly, our ancestors who touched the body, lovingly prepared it, wrapped it, built the pine box where it would decompose, had a stronger connection to the sense of finality of death.

Arguably the most significant twentieth century funereal development, the popularization of embalming had implications for every associated physical, social, emotional, and logistical aspect of death and funeral practices. After the 
introduction of embalming, corpses adorned in full makeup looked comfortably asleep. The corpse "could now be commodified in new ways" (Troyer 2007:34). As the body "began to look less dead," American mourners adjusted their perceptions and expectations of how a corpse should be presented. The practice resulted in a disconnect from direct familial management, and a movement towards allocating the domain of death and remembrance to a new industry.

The evolution of the contemporary funeral industry can be aligned with certain specific changes in professional practice and approach. The history of one specific mortuary institution, [what is now known as] The Cincinnati College of Mortuary Science, serves as an effective example of congruent social change and the evolution of funeral practices. In 1882, the Cincinnati School of Embalming offered a three-day course in basic chemical-based corpse preservation. In 1909, instruction was lengthened and took account of advances in knowledge of anatomy, disinfection, and thanatochemistry. Little changed until 1966, when the name "Cincinnati College of Mortuary Science" was adopted, along with revised curricula, to convey newly adopted higher academic standards and the "more complex nature of the profession." Today, as evidence of the expanded consumer expectations and simultaneous loss of professional autonomy of funeral directors, the college requires courses in "Pre-Need," "Cremation Fundamentals," "Business Law," "Vital Statistics," "Pathogenic Microbiology" and "Psychology of Grief." The CCMS website appeals to prospective students by advertising that the college's "diversity of students results in exposure to a national perspective on funeral service and to a broad perspective on life." 
Torres (1988) provides a cogent history of the professionalization of the funeral industry. The National Funeral Directors Association (NFDA) was launched in 1882 , lending legitimacy and exclusivity to the formerly vague occupation. Members of the association were united in a belief that implementing educational standards would further increase credibility. At that time, education of undertakers was based solely on embalming practices; expertise on the topic was associated with physicians and other medicalized professions. As a straightforward skill, embalming lacked potential for sophisticated progression beyond improved fluid content. By 1940, attempts at creating an embalmers' union led industry heads to expand the educational standards and the domain of the funeral director to include knowledge in legalities, grief, and funerary customs.

Funeral corporations expanded rapidly beginning in the early 1960s, as did mortuary/cemetery combinations and direct-disposition firms. Torres (1988) asserts that the appearance of these three developments eventually encroached upon the traditional funeral directors' monopoly over industry dictates of standard and expertise. In 1972, the first licensed accreditations of the profession were granted by the American Board of Funeral Service Education via powers allotted by the United States Office of Education. In that same year, the industry experienced massive investigation by the Federal Trade Commision. This investigation lasted through the early 1980s and was met by an (ultimately unsuccessful) united industry-wide effort mobilized by the NFDA to fight FTC rulings. 
Regardless of its approach, the constant essential substance of the funeral industry has been its role in conducting customary death rituals. Today, that role has been expanded to include the re-negotiation of existing rituals, or the innovation of entirely new ones. The work of Hochschild (1983:19) considers "what happens when feeling rules, like rules of behavioral display, are established not through private negotiation but by company manuals." This, in fact, is what occurs behind the scenes of the funeral industry. A review of the website of the National Funeral Directors Association (www.nfda.org) reveals the extent to which our rituals are corporately negotiated. For example, the following quote is from the National Funeral Directors Association's (NFDA) "Planning a Funeral" consumer resource tab:

A funeral service that is both meaningful and memorable should be as unique as the individual being remembered; it can reflect their personal values, interests and experiences. While planning a funeral service requires making many decisions during a difficult time, you want to organize an event that honors and highlights your loved one's life. A funeral is so much more than a way to say goodbye; it's an opportunity to celebrate the life of someone special. Today, a funeral can be as unique as the individual who is being honored. From simple touches like displaying personal photographs to events created around a favorite pastime, funerals can reflect any aspect of a person's life and personality. For additional ideas on personalizing a funeral, please contact your local NFDA funeral director.

With its hand on the pulse of consumer wants and needs, the funeral industry is a sophisticated conduit of the American psyche. The industry is exceptionally image conscious and acutely aware of society's opinion of its work.

This has not always been the case, as evidenced by Torres' (1988) extensive 
description of the industry's history. In the first half of the twentieth century, industry attitudes and operations remained relatively stable. By the late 1960s, however, Torres notes that American questioning of the status quo resulted in industry overhaul. Walter (2006) further discusses the impact of 1960 s media and pop culture on perceptions of death, and in turn, the funeral industry.

Jessica Mitford's contribution is considered a seminal piece of writing on the American funeral industry. Her 1963 book, The American Way of Death, was intended to be an investigative exposé on the (what she perceived to be) unsavory practices of the time. In the book, Mitford described the funeral industry as prohibitively expensive, overly sentimental, and highly commercialized. She accused funeral directors of greed and exploitation, citing what she perceived as callousness and the provision of unnecessary services. The book was published on the cusp of so much other social upheaval and hugely impacted American audiences. Several other media reports followed, and widespread public skepticism of industry practices ensued, all of which have persisted to date. The industry has never fully recovered from what Mitford incited.

The increasing popularity of cremation has greatly contributed to major funeral industry restructuring, according to Keallaher, Prendergast \& Hockey (2005). In 1960, cremation was the elected form of disposal for only $4 \%$ of all US deaths. By 2005 , cremation was chosen for $31 \%$ of all US deaths. For 2010 , it is projected that this will jump to $38 \%$, and to $51 \%$ in 2025 (US National Vital Statistics). Keenly aware of these figures, in 2008, the National Funeral Directors Association (NFDA) International Convention \& Expo sponsored a workshop 
entitled, "Yes You Can Profit From Cremation!" According to workshop documents, this workshop was intended to: 1) redefine cremation for consumers by raising the standard of cremation service offered; 2) identify positive and profitable approaches to providing cremation options; 3) recognize the financial opportunities of cremation; and 4) educate staff about proven and more rewarding approaches to cremation. Kastenbaum (2004) details the arguments on the choice of cremation, citing a shift from considerations of religious and public health dictates to prioritization of more options for disposal and memorialization.

\section{Theoretical Framework}

When considering any aspect of contemporary culture, Winkel (2001) says we must consider the cultural values of the era itself. Characterizing the culture of the twenty-first century, Lynch (2004:12) believes that social changes since 1970 have hugely impacted attitudes toward death and funeral practices. He cites changes in gender, family, mobility, religion, climate change and media as factors contributing to the contemporary perceptions of life and loss, and a focus on the impact of death on our self-identity. By contrast, Elias (1982) believes that an occurrence of death prior to 1950 was felt most as a disturbance to the larger

social network. In that era, because "identity [was] rooted more in the group than the individual, death [did] not threaten the individual as it does in the modern world" (Shilling 2003:163). Bloch and Parry (1982) support this idea by describing death as a loss of societal potential rather than individual potential. 
In general, today's postmodern American culture can be characterized by flexibility, diversity, and individuality. Mellor and Shilling (1993) focus on the relationship between self-identity and the structuring of death in contemporary social life, arguing that analysis of postmodern death rituals cannot be considered without a focus on the postmodern presentation of and preoccupation with the self. Their argument includes the need to consider heightened awareness of one's body and how it is appraised. Giddens (1991) identifies three central characteristics of high modernity, namely: the increased shaping of one's biography to construct a desired identity, an emphasized importance of the physical body in identification of the self, and decreased significance of the sacred. Most applicable to the exploration of this study are what Simon, Haney and Buenteo (1993: 412-417) identify as five notable aspects of change in the conduct of contemporary social life under the umbrella of postmodernism:

1. The normalization of persistent and diffuse change;

2. the abandonment of the concept of nature as necessarily embodying lawful regularity;

3. the death of telos, or the discrediting of history as a master, purposeful narrative;

4. adaptations to largely unanticipated levels of individuation; and

5. potential changes in the politics of the self.

As society has changed, so has its approach to ritual. As religious tradition, the notion of the "sacred" has dissipated, society has scrambled to fill the gaps left behind. Mellor and Shilling (1993) argue that this absence leaves more room for looking inwards, considering how construction of an identity has 
replaced the need for external spiritual validation. Values formerly promulgated by the Bible are now derived from a myriad of less than sacrosanct sources, which in postmodernity, were created to serve the purpose at hand. Hearkening back to Winkel's conception of social context, Wouters (2002) believes this secularization has developed alongside social, political and economic changes.

Hunter (2007-2008) poses the question this way: are new ritual practices being developed, or instead is a reformulation of traditional beliefs and practices occurring? Scholars variously use the terms de-ritualization, de-evolution and neo-institutionalization to describe these changes. Winkel (2001:68) refers to a "re-ritualization" occurring in Germany, and identifies bureaucratization and commercialization as playing a role in the modernization of death rites. GarcesFoley (2002-2003:300) believes that "self-expression has become its own ritual, functioning in the same way traditional religious rituals do." In other words, Garces-Foley's view is that the rituals of yesterday and today are equal in gravity, objective, and realization. Operating under the impression that enough Americans follow what she terms "golden rule theism" (i.e., characterized by a focus on living a good life, guided not by a specific theology, but a general desire to do good for others), Garces-Foley suggests that even a postmodern death memorialized in a postmodern funeral will embody ritual elements and some semblance of tradition.

In the social body-focused era (described by Elias 1982; Bloch \& Parry 1982) preceding late 1960s America, customary rituals were an opportunity to connect to the group. Now, rituals are an opportunity to learn about an individual. 
We were previously assured that our lives were meaningful, because a priest or rabbi or pastor or minister told us so. Our faith in the system of rituals was bolstered by assurance that our entrance into a peaceful eternity was guaranteed, so long as we were active participants. According to Winkel (2001) less formal and less emotionally charged conventions have replaced religiously based rites. As a result, whereas the traditional funeral was more akin to an instructional "lecture", the contemporary funeral operates as a casual "conversation". Bellah et al. (1985) believe that this phenomenon is a breeding ground for narcissism. Such a personality, he proposes, develops out of a diminished emphasis on morality which occurs in tandem with decreased religiosity.

Sociologists and anthropologists have recorded details of culturally variable mourning rituals, and attention has been given to how such customs are related to grief. However, much scholarly literature on grief (as well as books penned for the "average" mourner) portrays the emotion as a wholly private and individual experience. The "grief role" is a privilege granted to individuals deemed as worthy of such a role based on societal perceptions of a specific loss. Access to this role "establishes a benign social milieu that recognizes and makes allowances for the dysfunction and incapacity of the grieving person following a major relationship loss" (Fowlkes 1990:636). Of course, what is understood as "dysfunction" and "incapacity" is culturally based, and therefore has tremendous implications for if and/or how a bereaved person will choose to mourn publicly and privately grieve. 
Our expectations influence our grief, and our expectations are based largely on our modernity. Lofland (1985) identifies the postmodern perception of death as wholly aberrant except among the elderly, precipitating the question of how our youth and extended-life obsessed society develops a functional set of tools for facing death. At a time when no death is considered natural, acceptance of death becomes more difficult as people increasingly venerate the physical body and its inextricable link to self-identity (Mellor and Shilling 1993). According to Phillips (2007), our contemporary approach to memorialization is therefore a fitting indication of a contemporary ideology which resists death and embraces control and choice with regard to the business of dying.

Walter (1994:47) identifies three "ideal" types of deaths: 1) traditional, 2) modern, and 3) "neo-modern" (a combination of late modernity and postmodernity). Walter describes each type in terms of bodily context, social context, and authority. A "traditional" death is "quick and frequent" in bodily context, community is the focus of social context, and religion wields authority. In the "modern" type, death is hidden in bodily context, public dominates the private in social context, and medicine is the most esteemed authority. A "neomodern" death is prolonged in bodily context, the private becomes public with regard to social context, and the self is regarded the ultimate authority (1994:47).

Phillips (2007) believes that these three types of deaths are incongruous, resulting in confusing ambiguity and variability in present culture. In other words, such a factorial of approaches makes it impossible to convey a clear picture of death. A few other studies have identified and expanded what constitutes a 
postmodern death. In particular, the research of Simon, Harvey and Buenteo (1993) generally describe the characteristics of postmodernity, and detail its implications for societal change. They argue that these changes impact death practices to the point of re-invention. What makes a funeral "meaningful" is relative, but inarguably, the American funeral industry has adjusted to meet countless variations on perceptions of meaning. Kastenbaum (2004) notes that rapid "sociotechnological" shifts have distorted any shared meanings across generations with regard to the utility and import of death rituals.

Hunter's (2007-2008) research focuses on legacy creation and legacy transmission. In exploring the postmodern process of conscious and devoted legacy creation, she found that the most significant task to be a reflective determination of the values one prioritizes most, and discerning a method for how to ensure explicit impartation of those values for posterity. Many present-day Americans have a desire to do or leave something "more" as a part of their legacy, and this can now be managed via the funeral industry. The sentiment is not new; the avenue is. For example, in bygone eras, families named a grandson after his deceased grandfather in order to perpetuate the family name; this way of "keeping someone alive" is quaint in comparison to contemporary options for remembrance. Examples of our new devotion to maintaining a posthumous presence via tangible elements include creation of a funeral video or audiorecording, permanent online memorials, and social networking pages devoted to the deceased. Conscious creation of a legacy allows people to transmit their individuality even after death. 
Review of the literature indicates that despite other myriad disagreements, researchers agree on the following point: over time, there has been a decrease in the sacred associated with death and a marked increase in the perception of death as an individualized experience. Whether this phenomenon is positive or negative is hotly debated, pondering whether it is progress or degradation to adapt death practices to a postmodern ethos of self-celebration. Beck and Beck-Gernsheim (2002:151) document extensively the wider cultural of individualization, which they define in two ways: "1) disintegration of previously existing social forms (e.g., class, social status, gender roles, family, neighborhood, etc.), 2) the collapse of state-sanctioned normal biographies, frames of reference, role models." Ironically, it is further suggested that an individualized "life of one's own is a highly socialized existence, utterly dependent on institutions" (2002: 151). Walter (1994) introduces the idea of "mass produced individualization" in the postmodern assembly-line type choices of funeral elements. His model moves beyond funerals to implications for memorialization and ritualization. A precursor to Beck, Lofland (1985:179) notes that Turner (1976) and Turner and Gordon (1981) have provided "evidence for a recent shift in the location of the 'true self' from an anchorage in 'institution' to an anchorage in 'impulse."' In her explanatory discussion of what she terms "space-time variation in the character of the self," Lofland further alludes to the concept of individualization via Morris (1972) and Zurcher (1977).

Although he focuses mainly on examples from the Netherlands, Wouters' (2002:2) study cites Elias (1991) who identifies shifts during the 1960s and 1970s 
in what he terms the "we-I balance" of individuals. This shift is characterized by the prioritization of one's self, or "I-identity" over association with a larger social group, the "we-identity". Wouters (2002:2) elaborates on the work of Elias, describing a general cultural transition from a "we-identity" to an "I-identity". As a consequence of this trend, Wouters (2002) proposes that the need for socially prescribed rituals has declined. Complications associated with delegation of the creation of new expressive rituals to non-authorities are discussed. For example, Wouters (2002) believes that most attempts at ritual creation fail to appear authentic or even function effectively, though this does little to deter individuals convinced of the unique and valid capacity of the abstractions promulgated via one's "I-identity."

Relatedly, Bellah et al. (1985) believe that a combination of social and cultural contradictions have resulted in a common sense of individualism among Americans, characterized by ambivalence and ambiguity. Accordingly, we persist in acting autonomously to create a self-identity separate from any notion of cultural or social connection; then insist on the nurturing and fulfillment of that empowered "true self" as the guiding objective of the quest to lead a meaningful life. In other words, autonomy is a paramount tenet of individualization. Correspondingly, Philips (2007:330) notes that what we as Americans determine to be a "good" death is "increasingly seen as a death in which the individual maintains authority, with ultimate control over social, cultural, medical, religious and legal concerns." 
The control that families exercise over matters of death is highlighted by the obituary, the formalized summary of an individual's presentation of self. Phillips (2007) analyzes the changing presentation of death in the newspaper obituary and focuses on the shift from brief obituaries that make distinct mention of the matter of death to today's soliloquies highlighting the uniqueness of the deceased. Recent obituaries are far more likely to list the deceased's accomplishments and less likely to mention how the person died (beyond requests for donations to a charity, for example).

How does a society rooted in individualization indoctrinate its constituents to grieve? Western modes of thinking dominate the literature on grief theory and mourning, evidence of which can be seen in the expression of time as linear, an emphasis on a medical model, and the prominence given to autonomy. The current emphasis on 'letting go,' pervasive throughout popular, scientific, medical, psychological and media cultures, ensures that the bereaved have an idea of how they are 'supposed' to behave in the face of grief, and contributes to the offerings of the funeral industry. Lynch (2004) believes that in contemporary detraditionalized society, popular psychological maxims have replaced conventional religious rites. Subsequently, psychologists are granted the power to dictate to both individual and industry which practices related to death, grief, and mourning are purposeful, efficient, and "psychologically correct."

Mourning etiquette has evolved from a $19^{\text {th }}$ century prescription for how to grieve. In that earlier era, as protocol prescribed proper mourning dress, feelings literally were worn on one's sleeve. Now, however, postmodern 
discourse offers abundant yet nebulous notions of how to signify death. Just as the adoption of nineteenth century embalming methodology altered the course of the death industry, the innovation of countless new practices, products and ideas are doing, and will continue to do, the same. Foltyn (2008) posits that a society's notion of death is parallel to its notion of life. As we have become increasingly preoccupied with our perceived uniqueness, as therapy has lost much of its stigma, as an awareness of environmental impact has increased, and as the death industry transforms our options, the way we memorialize has evolved.

Much can be learned about a society from how it chooses to signify pivotal events, and we are experiencing a definitive new era in the American death industry. As an introduction to discussion of the evolution of industrial approaches to memorialization, it is necessary to question the sociological significance of why we do what we do to commemorate death. By cultivating an awareness that the explanation lies partly beyond our consciousness, we as individuals are empowered to recognize when we are manifesting a particular social instruction, seek out the locus of the prompt, trace its genesis, and ultimately, alter our feeling and behavioral patterns. In this study I attempt to identify those cultural mechanisms dynamic enough to result in the transformation of an entire industrial approach to what is arguably the most significant of all biographical events. It is not possible to consider the evolution of the contemporary funeral industry without considering the practices and ideologies that fall within its domain, and that is the approach to answering the central 
research question of this thesis: How has the American funeral industry evolved since $1963 ?$ 


\section{CHAPTER III}

\section{METHODS}

To explore the research question, a combined content and textual analysis approach was used. Articles from a leading funeral industry trade journal, Mortuary Management, were selected randomly and subjected to analysis. Mortuary Management is an American funeral industry trade publication intended for persons working in or related to the funeral service industry. Through a review of journal articles based on a prepared and vetted content and textual analysis approach, I attempted to answer the following specific questions in this thesis: 1) What themes emerge from content and textual analysis of the funeral industry trade journal Mortuary Management? 2) How did the focus of the industry shift on the specific chosen domains? and, 3) What does trade journal content indicate as possible mitigating factors in industry change?

According to its website, Mortuary Management magazine "brings continual analysis about the ever-changing service of death care (www.mortuarymanagement.com)." Members of the William Berg family of Salina, Kansas, owners of the Berg Undertaking Company, developed and released the first issue of the journal through Berg Publications, Inc. in March 1914 under the name Pacific Coast Undertaker (which remained until the 
transition to Mortuary Management in 1926) ("History of Mortuary Management" August 1964). In 1975, Abbott and Hast Publications, Inc. (a division of Abbott and Hast funeral support company) purchased Berg Publications, Inc., and assumed publication of Mortuary Management. The table of contents page includes a quotation from the publisher stating that Mortuary Management magazine is a trade publication "designed for funeral directors and others related to the funeral service industry, including manufacturers, suppliers and dealers of funeral merchandise and equipment, embalmers, cemeteries, and mortuary science students and colleges."

The choice to analyze Mortuary Management was based on availability (it is identified by the publisher as "one of only two independent monthly funeral magazines"), reference to the magazine in journal articles consulted for literature review, and its age and established market presence. The journal is offered monthly by subscription (except for a combined July/August issue) to funeral home owners, staff members, service and supply industries and mortuary students. No specific circulation figures are accessible; (put in semicolon) however, a quotation on the publisher's web page states that "thousands" of death care professionals read Mortuary Management every month. Subscription rates in the United States are $\$ 39.00$ per year, and $\$ 65.00$ per two years (in 2010 dollars). Single issues may be purchased from the publisher for $\$ 10.00$ per copy. With offices in West Bloomfield, Michigan; Tiburon, California; and Milwaukee, Wisconsin, Abbott \& Hast Publications claim to be "uniquely qualified to bring pertinent information to its readers" (www.abbottandhast.com). 
Attempts were made to obtain journal issues dating to the beginning of the publication (March of 1914 under the original name Pacific Coast Undertaker). Unfortunately, this proved overly difficult and prohibitively expensive. After searching libraries throughout North America with holdings of the journal (all of which had incomplete collections), the most complete and extensive collection of journals available was ultimately retrieved from the Cincinnati College of Mortuary Science. The College has a collection of Mortuary Management journals dating from 1963. Consequently, 1963 was chosen as the first year of study primarily as a matter of convenience. As the literature review and article analysis were undertaken, however, it became clear that the determination was fortuitous due to the parallel occurrence of significant and groundbreaking social events. For example, 1963 saw the assassination of President John F. Kennedy; Martin Luther King delivered his "I Have a Dream" speech; the Beatles debuted in the U.S; Betty Friedan published The Feminine Mystique; Jessica Mitford published The American Way of Death; major gains were made in space exploration; and U.S. involvement in the Vietnam War escalated. Effects of this synchronicity were momentous and rippled to every facet of society. As an enterprise necessarily abreast of consumer whims, the funeral industry reflects the impact of these events throughout the pages of Mortuary Management.

Two articles per year from the 46-year period spanning 1963 to 2009 were identified as units of analysis. In total, 92 articles were read and analyzed (Appendix A). To identify which articles per year would be utilized, using a random number table, each issue year from 1963 to 2009 was assigned two two- 
digit figures which translated to months of the year. For example, beginning with the year 1963, the digits 11 were identified from the initial random number string of 11458. The digit 11 was then correlated with the month of November. In the instance that a particular issue was unavailable, the next consecutive month's issue was utilized. From each issue, one feature article was chosen for analysis. Articles were examined using both a qualitative textual analysis approach and a quantitative content analysis notation of mentions of 18 pre-determined variables, including: tradition, change, religion, secularity, cremation, embalming/corpse preparation, alternatives to traditional rituals, physical business matters, ritual particulars, industry image, consumer wants/demand economics, new idea, new product, sustainability, corporate practices, grief services, personalization of industry services, and individualization of death rituals. When the focus of a particular article was outside the realm of the chosen domains, a notation was made. Examples of article topics not contained in the list of pre-determined variables include: education, tax litigation, advertising, profit loss, association membership, and economics. Although this miscellaneous content was identified, no thematic pattern emerged, and these data were not used.

Working in collaboration with a communications professor with expertise in content analysis design and implementation, a content analysis instrument (Appendix B) was developed. The specifically formulated instrument intended to capture generic topics typical to trade writing as well as specialized topics related to the essence of the funeral industry. Following an initial literature review related to the history of the funeral industry, items were identified for inclusion. 
The instrument was revised several times and adjustments were made to confirm clarity, combine similar domains, ensure the inclusion of all vital categories and eliminate any redundancies. In order to test the content analysis instrument, three individuals were asked to read one article from Mortuary Management and complete the accompanying protocol. Testers were asked to read for clarity and provide any feedback on ambiguous aspects of the instrument. Comments were taken into consideration and the instrument was amended to incorporate edits as agreed upon by all three readers and the lead author.

The content analysis instrument was developed based on an initial review of relevant literature, examination of Mortuary Management articles (not used for final analysis), and examination of other industry-related trade publications, including web-based resources such as the website of the National Funeral Directors Association and TheFuneralGurus.com. Following this review, a list of potential variables was devised. The list was pared down to a manageable number of only the most relevant and significant topics. Choice of variable is attributable to: common themes, allusions to subject matter, historical considerations, cultural media presence, and theoretical considerations of postmodernism and individualization. The chosen items adequately reflect what preliminary research revealed to be particularly critical and/or indicative elements.

It was necessary to determine conceptual and operational definitions for each variable. In addition to the variables shown in Figure 1, the content analysis instrument was used to code these items: date of publication, author, and article title. A straightforward and uncomplicated picture of themes often or rarely 
present was produced by cataloging each article in this method; these data thus informed my approach to the subsequent textual analysis. 
Figure 1. Conceptual and Operational Definitions of Variables

\begin{tabular}{|c|c|c|}
\hline Variable & Conceptual Definition & $\begin{array}{l}\text { Operational } \\
\text { Definition }\end{array}$ \\
\hline Tradition & $\begin{array}{l}\text { A long-established or inherited way of } \\
\text { thinking or acting }\end{array}$ & $\begin{array}{l}\text { At least one mention of } \\
\text { tradition }\end{array}$ \\
\hline Change & $\begin{array}{l}\text { Variation from the culturally established } \\
\text { norm }\end{array}$ & $\begin{array}{l}\text { At least one mention of } \\
\text { change }\end{array}$ \\
\hline Religion & Observance of spiritual faith and beliefs & $\begin{array}{l}\text { At least one mention of } \\
\text { religion }\end{array}$ \\
\hline Secular approach & $\begin{array}{l}\text { Approach not pertaining to or connected } \\
\text { with religion }\end{array}$ & $\begin{array}{l}\text { At least one mention of } \\
\text { a secular approach }\end{array}$ \\
\hline Cremation & $\begin{array}{l}\text { The funeral rite of reducing a dead body to } \\
\text { ashes by fire }\end{array}$ & $\begin{array}{l}\text { At least one mention of } \\
\text { cremation }\end{array}$ \\
\hline $\begin{array}{l}\text { Embalming/corpse } \\
\text { preparation }\end{array}$ & $\begin{array}{l}\text { Preservation of a dead body (typically with } \\
\text { the intent of showing the body) }\end{array}$ & $\begin{array}{l}\text { At least one mention of } \\
\text { embalming or corpse } \\
\text { preparation }\end{array}$ \\
\hline $\begin{array}{l}\text { Alternatives to traditional } \\
\text { rituals }\end{array}$ & $\begin{array}{l}\text { Ritualistic actions which deviate from the } \\
\text { established methods }\end{array}$ & $\begin{array}{l}\text { At least one mention of } \\
\text { an alternative to } \\
\text { traditional rituals }\end{array}$ \\
\hline Physical business matters & $\begin{array}{l}\text { Matters dealing with the physical operation } \\
\text { of the funeral industry }\end{array}$ & $\begin{array}{l}\text { At least one mention of } \\
\text { physical business } \\
\text { matters }\end{array}$ \\
\hline Ritual particulars & $\begin{array}{l}\text { A culturally prescribed proceeding; specific } \\
\text { elements of a culturally prescribed } \\
\text { proceeding }\end{array}$ & $\begin{array}{l}\text { At least one mention of } \\
\text { a ritual particular }\end{array}$ \\
\hline Industry image & Public perception of the funeral industry & $\begin{array}{l}\text { At least one mention of } \\
\text { industry image }\end{array}$ \\
\hline $\begin{array}{l}\text { Consumer wants/demand } \\
\text { economics }\end{array}$ & Desires of the customer & $\begin{array}{l}\text { At least one mention of } \\
\text { consumer wants }\end{array}$ \\
\hline New idea or practice & $\begin{array}{l}\text { A concept or act not previously utilized by } \\
\text { the funeral industry }\end{array}$ & $\begin{array}{l}\text { At least one mention of } \\
\text { a new idea or practice }\end{array}$ \\
\hline New product & $\begin{array}{l}\text { Goods not previously utilized by the funeral } \\
\text { industry }\end{array}$ & $\begin{array}{l}\text { At least one mention of } \\
\text { a new product }\end{array}$ \\
\hline Industry sustainability & $\begin{array}{l}\text { Potential for viable continuation of the } \\
\text { funeral industry }\end{array}$ & $\begin{array}{l}\text { At least one mention of } \\
\text { industry sustainability }\end{array}$ \\
\hline $\begin{array}{l}\text { Corporate } \\
\text { practices/takeover }\end{array}$ & $\begin{array}{l}\text { Actions of one of many funeral industry } \\
\text { corporate conglomerates }\end{array}$ & $\begin{array}{l}\text { At least one mention of } \\
\text { corporate } \\
\text { practices/takeover }\end{array}$ \\
\hline Psychological/grief services & $\begin{array}{l}\text { Services intended to acknowledge and } \\
\text { alleviate feelings of grief due to death }\end{array}$ & $\begin{array}{l}\text { At least one mention of } \\
\text { grief services }\end{array}$ \\
\hline $\begin{array}{l}\text { Personalization of industry } \\
\text { services }\end{array}$ & $\begin{array}{l}\text { Tailoring approach to clients based on } \\
\text { circumstances }\end{array}$ & $\begin{array}{l}\text { At least one mention of } \\
\text { personalization of } \\
\text { industry services }\end{array}$ \\
\hline $\begin{array}{l}\text { Individualization of death } \\
\text { rituals }\end{array}$ & $\begin{array}{l}\text { Particularize and make distinct proceedings } \\
\text { associated with the recognition of a death }\end{array}$ & $\begin{array}{l}\text { At least one mention of } \\
\text { individualization of } \\
\text { death rituals }\end{array}$ \\
\hline
\end{tabular}


When choosing the appropriate methodology for this research, I considered the need to provide both verifiable data as well as a "thick" description allowing for the explanation of inter-textual subtleties. In order to construct a clear and confirmable record of the data, I relied on a simple quantitative content analysis approach to count the appearance or nonappearance of each item for each article. However, merely counting the number of mentions of specific variables ignores the nuance of context. Beyond noting the significance of an allusion in a certain year's issue, it was vital to identify the tone and attitude of that allusion. For example, did an article convey disdain or to show support for an issue? In order to augment the straightforward tabulated findings, a qualitative textual analysis technique was also utilized. Through textual analysis, themes are discovered and considered with regard to attitude and linguistics, and interpreted according to corresponding cultural circumstance (Thornton 2002: 109).

Employing both methods results in a more expansive and illustrative portrayal of the data. While content analysis offers a plain demonstration of information in an ordered format, textual analysis allows the researcher to note context, nuance and tone in a more descriptive way (Musso \& Wakefield 2009: 21). Content analysis is particularly useful when studying copious amounts of data spanning several decades (in the case of this research, 92 articles covering 46 years), and reveals surface-level trends and patterns (Yoo 2001). In-depth textual analysis allows the researcher to explore patterns through analysis of publication date and concomitant social context, attitude of the author, allusions to any 
relevant data not counted in the content analysis, and any notably illuminating direct quotes.

This integrated approach was necessary in order to explore the substance and meaning of each article. For example, content analysis shows that a 2004 Mortuary Management article mentioned "religion," but that mention does not by itself reveal that the author was noting the decline of religious sentiment in funerals: "Many do not find value in religious influence on services or formalities as they know them to be" ("Selling, Renting, Buying and Donating Bodies" July/August 2004). Thornton (2009: 109) notes that by combining these methods, researchers can "examine the main organizing ideas that suggest why given events are important and how they are to be understood. It is then possible to ascertain the specific ways certain issues are given prominence, while others are delegitimized or ignored." Ultimately, because of an awareness of history and framework, textual analysis results in a more vivid and specific extension of empirical data. 


\section{CHAPTER IV}

FINDINGS

This study sought to investigate the research questions: 1) What themes emerge from content and textual analysis of the funeral industry trade journal Mortuary Management? 2) How did the focus of the industry shift on the specific chosen domains? and, 3) What does trade journal content indicate as possible mitigating factors in industry change? Analysis of selected articles revealed that, between the decades spanning 1963-2009, the funeral industry has steadily attempted to maintain sociocultural relevance through adaptation to the postmodern ethos of informalization and mercuriality. A number of common themes emerged through examination of the data. Most notably, content and textual analysis revealed six primary thematic foci. These themes are:

1) Industry preoccupation with continued social and cultural relevance through a steady rumination on change

2) Decreased ritual significance of religion

3) Coping with a dismantling of traditional rituals; movement toward highly individualized rituals based on consumer demands

4) Normalization of cremation; movement away from the corpse as the most significant element of the funeral ritual 
5) Preoccupation with image maintenance, and social and economic sustainability

6) Acknowledgement and incorporation of grief services

Findings are presented here as six sub-sections devoted to each thematic category, including: 1) Change; 2) Religion; 3) Ritual; 4) Mode of Disposal; 5) Image; Sustainability, and Commerce; and 6) Grief.

\section{Change.}

Mentions of change in Mortuary Management begin in the earliest year of this data set (1963), and appear regularly throughout the period studied. Authors alternately question the validity of change, accept it grudgingly, recognize it as the industry's one true constant, encourage its exploitation, and spend much time entertaining questions of the "progress paradox" or the "paradox of choice."

A reflection of cultural preference, in 1926 the title of the journal was renamed from Pacific Coast Undertaker to the current Mortuary Management. Articles throughout the journal's history encompass sweeping changes to health and safety requirements, pricing schedules, the scope of work of the funeral director, expectations of clients, and most conspicuously, the perception and purpose of death rituals. Truly, nothing in the future of the industry is predictable. This has been hinted at for decades, but in the few recent years, monumental social and industry developments have proved it. 
In these data, the first mention of change is a rejection of it. In 1963, the Funeral Consumers Alliance, a nonprofit group comprised of memorial societies, was created to promote simplified and affordable funeral options and to protect consumer rights. That year, a journal contributor reacted to the recent development and increased exposure of memorial societies as follows: "Dr. Scott made this comment which I thought was very pointed. He said: 'This is not communism- it is atheism. Many people would find much more sentiment provoked in the death of a pet.... Let us look upon the memorial society as a warning" ("The Past is Prologue" January 1963). As early as 1963, the industry was feeling threatened by external forces encroaching on the death domain. By equating memorial societies (and change) to atheism and communism, the industry was hurling the worst insults imaginable at the time in the direction of the threat (and directly reflecting widely held cultural beliefs of the era). This 1963 Mortuary Management author continued by advising his industry peers: "We must be consistent with our standards. You see, any likeness to communism as reflected in a memorial society comes not in un-American activities or attitudes, but comes from unbelief" ("The Past is Prologue" January 1963).

A 1964 article offers a clearly articulated summary of the then-current perception of the "specific purposes and values of the funeral...: a funeral faces the reality of death--does not avoid it; a funeral provides a setting wherein the religious needs of the bereaved may be satisfied; a funeral provides faith to sustain spirit; a funeral helps free one from guilt or self-condemnation; a funeral helps one express feelings; a funeral directs one beyond the death of a loved one 
to the responsibilities of life; a funeral, in a personal way, helps one face a crisis with dignity and courage; a funeral above all provides an environment where loving friends and relatives can give the help needed to face the future with strength and courage" ("A Westerner Views Education" September 1964).

Vitriol for Jessica Mitford's The American Way of Death (and her proposed revision of the funeral industry) is wholly unmasked. Mitford is directly insulted in 1964 as a bush-league dissentient: "Her [Jessica Mitford's] suggestions for change are the most incompetent of all...She supports the memorial society approach to the funeral which violates all of the basic principles of wise and healthy grief management" (A Westerner Views Education” September 1964). Contrary to the industry's dismissal of Mitford as ignorant, her impact on the country's perception of American funeral and death traditions was immeasurable and effected systemic industry reform and innovation.

The industry begins the 1970 s by addressing the massive social and cultural changes occurring in other sectors of society and considering what impact the Civil Rights movement, the anti-war movement, women's rights campaigning, consumer rights movement, etc. would have on perceptions and preferences in matters of death. "In any event, we find Americans are undergoing a "crisis in values.' Human values and gut convictions, strongly influence the behavior of our nation. Many ask, 'how are young people feeling about funerals today? Are they going to feel that way tomorrow when they have a family and a job? Is it just the difference between generations so that today's young people, when they reach 30 , 
will think like other 30 year olds we've known?", ("The Image of Funeral Service" July/August 1970).

By 1976, the industry had distanced itself from its aforementioned 1964 pronouncement of the purpose of an American funeral. In 1976, the industry, "define[s] the funeral in terms of its therapeutic value to the persons present. More emphasis is placed on comfort to the bereaved than on salvation for the deceased. Our research shows that, in the main, this therapeutic concept of the funeral is rapidly becoming the aim and purpose of most of the clergy" ("Let's Not Take the Funeral for Granted" March 1976). There remains some emphasis on religion; the author mentions salvation, and the statement assumes that funerals are facilitated by a person associated with the church. This description illustrates a transition from a ritual intended to confront and face death, to a presentation for the therapeutic and reminiscent benefit of the living.

In the same year, the journal initiates a question that the industry had only recently begun to consider, yet remains a constant consideration to the present day (due to the fact that the answer changes relentlessly): the question of meaningfulness, as in, "what makes a funeral meaningful?" A 1976 contributor poses the thought this way: "[The public] may think that the rolling stock was great, the casket just right and the personnel most helpful; but if the funeral service itself is meaningless or offensive to them, everything means nothing" (Let's Not Take the Funeral for Granted" March 1976.) Ideas about meaningfulness vary, but the industry's stance appears to be "we aim to please," regardless. 
Change is welcomed in 1997 when it represents a new avenue for expanding business opportunities. Again, the industry seizes the zeitgeist by incorporating the position of increased significance enjoyed by American pets into the ever-growing list of service options. In 2000, the industry touts pet internments as a noble and worthwhile endeavor: "Don't trivialize this issue by offering pet internments as 'just another item' on your price list. Helping people get through a very tough time, for many, as devastating as the loss of a child-- that is what it is about" ("Pet Cemeteries Help Recognize Pet Bereavement" September 2000.) As what we value as a culture continues to shift, the funeral industry morphs into a pet-honoring, life-celebrating, grief-supporting, eventplanning conglomerate. To wit: "If we are to survive, we must have more than a 'willingness' to do whatever a client may want" ("Audience-Generated Funerals, And More" March 2005).

The transformation brought about by the increasing popularization of cremation has been, is currently, and will continue to be immeasurable, and the industry knows it. A 2005 contributor succinctly states the quandary: "Most of us listen and do our best to offer options, but we are still primarily stuck in the base issues of transportation, embalming, casket, visitation, funeral and cemetery. Many of us are now experiencing final care at the crematory, as cemetery finality is becoming a fading alternative" ("Audience-Generated Funerals, And More" March 2005).

The decline of tradition and a lingering attachment to the past are both hinted at and loudly expressed here. As "rules" for what is right and wrong and 
expected fall to the wayside, articles devoted to practices such as blasting one's cremains into outer space appear with commentary such as, "It is getting difficult these days to even remember what is traditional and what is not about this matter of funerals" ("American Funeral Service is...Out in Space!" March 1985). Amidst the articles advertising trendy new products and services, the industry expresses skepticism of the naiveté of blindly accepting every new fad. For some in the industry, the self-assured egoism of pre-1963 persists. For example, in 1992 a contributor states, "Those in American funeral service who become terrified when the news media picks up on new marketing techniques need to remember that new ploys often make good reads" ("Third Party Sellers: Distracting Mosquitoes in the Funeral Marketplace" July/August 1992). Such disdain is expressed by others, yet in nearly every instance is followed by a remark about the futility of protest, and the inevitability of change. Ultimately, some in the industry develop a flexible, lenient, and even welcoming attitude toward change, as evidenced here:

Contemporary American funeral rites, rituals, customs and ceremonies reflect myriad persuasions such as race, religion, lifestyles, vocations, income, social status, philosophies, traditional values and geographical influence. Diversity is the bedrock of the death care institution. American funeral service is the stage upon which diversity, uniqueness and persona are crafted and performed to commemorate and honor the individuality of life. Each and every life. ("A Cowboy's Funeral" May 2002)

"Progress" with regard to technological advances has had tremendous impact on the funeral industry. In keeping with the times, it is typical for modern 
funeral homes to host a comprehensive website. The history of the business is often prominently touted on these pages. Statements such as "Ours is a tradition of service" or "family owned and operated since [date]" are designed to put the bereaved at ease and trigger a feeling of "this place and these people will help me to know how to properly navigate myself and my emotions now." So important is this impression that, according to a report by the Federal Trade Commission, those funeral homes part of larger corporations and are not family-owned, often act to appear as if they were. As the postmodern disregard of "history as master" mushrooms, however, proud pronouncements of tradition are being replaced by demonstrated prowess of social networking sites, web-based funerals, and advanced utilization of audio-video technology to "enhance the funeral experience."

A significant mode of change within the industry has been consideration of the culture at large and an exploration of the world outside immediate regional boundaries. Historically, locale dictated many death ritual norms. Expanding knowledge and necessity of a comprehensive service array, coupled with the consumer demand for unique offerings, affected institutional change. A 1991 Mortuary Management contributor discusses the industry's new approach to contemplation of foreign customs, noting: "To get an idea of what was happening in our industry throughout the world, in 1991 we began to travel, looking past our own shores toward Europe and beyond, as we traveled to Spain, France, Germany, England and The Netherlands." ("Why a Trade Show for the Funeral Industry?" January 1997). In decades prior, it was outside the mental milieu of 
most Americans to consider that, for instance, as a contrast to our corpses madeup to appear peacefully asleep, outgroup corpses on view actually "look dead" (Walter 2005). We tend to take for granted that the way our community undertakes ritual institutional practices, and do so without consideration of the way such actions are practiced elsewhere. As globalization amplifies, multicultural death practices are occurring throughout America, and these data indicate that the industry is scrambling to become educated and adept at handling such diversity.

As demonstrated in later articles, one source of significant industry change is in body disposal options. As more and more Americans adopt a heightened eco-consciousness, the extent of a "green" lifestyle spreads to nearly every industry imaginable, including the death industry. There are indications in these articles of appeals to a new environmental awareness. This growing trend lends itself to death rituals in the form of green burials, home funerals, and various methods of participation in funeral design and corpse preparation. In 2009 , the industry looks at the movement not only as a new trend, but as a new fiscal consideration, "new funeral home design should also push energy conservation and the 'Green Movement' as far as possible, but with reasonable cost. At the present, the 'Green Movement' is butting heads directly with current economic realities" ("Funeral Home Design and Maintenance" April 2009).

Funerals and death rituals, like so many aspects of the contemporary American experience, have become very complicated. The funeral industry is both shaping and being shaped by postmodern social affinities. Consumer values 
today are unparalleled in terms of diversity and magnitude; those values influence our preference of products, services, and alliances. Choices we make in modern society function as an indication of our values and identity (Bellah et al. 1985). In most cases, this fact is in the forefront of the decision-making process. Opting for an alternative death ritual is just one more way to advertise 'who you are.'

Examples of optional ritual accessories include a specifically designed cremainsscattering tube; opting for water resolution (an environmentally-friendly process that dissolves the corpse to "bone shadow" through heated steam pressure) as an alternative to cremation; recording a "Keepsake" video; wearing "Everlasting Memorial" jewelry (with a "discreet urn" designed to hold cremains) or a "Thumbie" (a piece of jewelry imprinted with the fingerprint of the deceased). In this era funeral directors are equated to wedding planners:"Just how different are funeral directors and wedding planners?...Look at the marketing used by wedding planners and try to imagine them applying to your business: It's your special day; who will you trust?; we are experts at listening to your needs" ("Weddings and Funerals" June 2008), such accoutrement are akin to the personal choices a bride makes about flowers, dress, and favors.

Discussion of change is nearly constant in the pages of post-1962 Mortuary Management. Contributors regularly admonish their more traditional colleagues to "wake up" and see the future for what it is. The particular vision often changes, however, based on the author. Whether a change is positive or negative is refuted, as is whether there is a way to combat the change, and who or what is to blame. What is agreed upon is that diffuse and persistent change is the 
new norm. Within the domain of change, the persistent patterns throughout this dataset are: 1) concession of the new constancy of change; 2) alternately discrediting or embracing specific change; and, 3) threatening messages to the industry about the consequences of refusing to change.

By 2009, the data suggest there is no prescription for a modern funeral. Death is no longer necessarily guided by religion, tradition, or cultural dictates of acceptability. Articles analyzed for this study indicate that with regard to the domain of "change," the funeral industry has attempted to adapt to a mutable and mercurial social landscape. One dictate of postmodernism is the "normalization of diffuse and persistent change" (Simon, Haney and Buenteo 1993: 412-417). If the American funeral industry has not wholly succeeded in changing in a sustainable way, these data suggest that it has at least succeeded in harboring awareness that there are no certainties in the trade.

\section{Religion}

Up until roughly the last quarter of the twentieth century, the majority ruled in the domain of religion with regard to the funeral industry. It was assumed that the majority of American citizens were "religious" (i.e., believed in a Christian god), and thus, religious allusions were casually interspersed throughout the journal. Funerals have traditionally been held as religious life-course transition rituals (Cook and Walter: 2005). Religious content, rituals, and traditional dictates have decreased as salvation of the deceased has largely been 
replaced by therapy for living and celebration of life as primary reasons for commemorating a death. Over time, funeral homes and funeral directors gradually became more open to facilitating funeral services catering to non-Christians, nouveau Christians, and persons with no religious affiliation. Abated focus on religiosity in death rituals has led to overt linguistic changes. Whereas the term "funeral" evokes ritual and religion, connotation of the increasingly common term "memorial service" is of a less-formal, secular or non-religious service.

It is necessary to distinguish between religion and westernized Christian religion. For the most part, and in every pre-1979 mention, Mortuary Management writers alluding to religion were referencing a western Christian creed. For example, a 1963 article touts one funeral home's custom of decorating their grounds with a nativity scene during the Christmas season: "The nativity scene is a tradition in this community and has attracted thousands of people every Christmas to the display and our city... This is done to give modern youngsters a chance to understand the true meaning of the Christmas Story, 'Put the Christ Back into Christmas"” (“Outdoor Displays for Religious Holidays" November 1963). The writer encourages his colleagues to consider similar displays. Of course, the underlying supposition is that such an exhibit would not only have mass appeal, it might also attract new clients. A 1964 article discussing the current state of affairs in mortuary education refers to the "Master Teacher" (i.e., Jesus), and his maxim, "He that would be greatest shall be the servant of all." The author continues by suggesting that his mortician peers "look upon [themselves] 
as instruments of God in helping him to fulfill man's needs" ("A Westerner Views Education" September 1964).

In 1963, a Mortuary Management contributor equates atheism to communism, perhaps the worst of all insults at the time. In the same year, those rare persons who chose cremation were equated to heathens. This unctuous attitude, however, persisted with such intensity for only a short time. Industry change was forced by the new social consciousness of late 1960s America. The industry's reconstitution of religion was effectively recognition of the diversity of religions and an acknowledgement that some Americans claimed no religious affiliation at all. The transitioning religious landscape was not an elimination, but rather an alteration to a more lax, less-institutionalized approach that better fit the myriad social movements introduced in the late 1960s. Americans were exploring Eastern religions, alternative spiritualities, and sometimes abandoning religion altogether. These data suggest that the funeral industry gradually recognized that in order to continue to attracting new clients, it was necessary to adapt to the new religious scene.

Most notably, funeral directors welcoming a family could no longer assume that their new clients were interested in the typical Christianity-rooted, church-based, clergy-led ceremony; data indicate that this new reality became more commonplace with every new year. Article allusions reflect recognition that history and tradition would not dictate religion's role in the future. This is sometimes expressed begrudgingly, and certainly not immediately embraced. For example, a 1971 article, in a passive concession of the choice of some Americans 
to live a non-religious lifestyle, asserts a psychosocial theory about the exceptional role of end-of-life choices: "The concept of most religions that death is a final rite appears to be deeply imbedded and emerges to influence behavior at the time of death, regardless of previous disregard of other religious tenets" ("A Funeral Service Investigation" February 1971). In context, this quote can be interpreted as the industry resisting change while acknowledging that adjustments will be necessary.

Ultimately, references to God and mainstream religion do not disappear completely from Mortuary Management, but rather are contrasted by additional open-minded references to alternative, and in some cases, wholly unconventional approaches. A 1979 article entitled "Two Wheelers Pay Their Respects" describes the funeral of the head of a Harley-Davidson motorcycle gang. The writer states that, "The officiant of the service was referred to by club members as The Pastor of the Church of the Free Highway -- an unlikely designation for a clergyman, but as representative of their spiritual values as minister or priest would be of ours" ("Two Wheelers Pay Their Respects" April 1979). The tone of the article is one of acceptance and interest in considering similarly unorthodox phenomena.

One of the clearest signals that religion no longer dictated the norms and mores of death rituals is a 1988 assertion that, "Funeral directors don't need preachers anymore in leadership positions. That time is long-past. For some strange reason, NFDA [National Funeral Director's Association] officialdom can't digest that message" ("A Mid-Summer Pot-Pour-Ri of American Funeral Service" July/August 1988). Although the industry's national organization is 
apparently attempting to maintain some sense of religious inclusion and authority, this article implies that practicing funeral directors dismiss the notion as futile.

At the beginning of the twenty-first century, one 2002 Mortuary Management contributor expresses annoyance at the inflexibility of conservative religious stances (i.e., Catholicism and Lutheranism), and touts the accepting and accommodating stance of the notoriously über-liberal Unitarian church:

Seeking a more economic alternative among the churches (although the deceased was not what you'd call religious), the Catholics, the church of his baptism, would not permit a memorial service unless the cremated remains were immediately buried- complete and undivided- in hallowed ground. 'You don't think you can just scatter the ashes, willy-nilly, to the winds, do you?' asked the immovable priest. Distracted by upcoming holiday services, the Lutheran minister (the pastor of his sister's family) agreed to do the service 'sometime after the first of the year', but made it clear he cared less for the life of the deceased than rounding up sinners for salvation. My niece thought of the Unitarian church in which she'd been married...the minister handed them a few pamphlets about the UnitarianUniversalists and said, 'If any of your friends want to know what this crazy-ass church believes, this will help you explain' ("If Necessity is the Mother of Invention, Beware the Unitarians" March 2002).

It is worth mentioning that as further evidence of the collective social and cultural informalization, this article includes the phrase "crazy-ass church" and an admonition to avoid "blather[ing] about God or heaven or hell or anything else overtly religious" ("If Necessity is the Mother of Invention, Beware the Unitarians" March 2002). Also a far cry from the incrimination of atheists in 1963, by 2005 an article neutrally points out that some clients are "quick to say 
they don't want a priest or minister involved [in funeral proceedings]"

(“Audience-Generated Funerals" March 2005, brackets added).

These data indicate that, compared to the aforementioned watershed moments in the industry's history, shifts in religious attitudes have not garnered as much specific attention. The decrease in ceremonial religious overtones is actually wrapped up in the larger postmodern social trend toward informalization. It does not appear that the industry considered this component singly, but rather as just one more aspect of the changing American social landscape. No real fanfare or outcry is detectable in this set of articles. In many ways, diminished funereal emphasis on religiosity actually opened the doors for industry expansion. Despite some initial difficulty adjusting to decreased association of religion and death, these data suggest that the industry has by and large acquiesced to consumer demand for services reflective of restrained religiosity, diversified religiosity, or the absence of religiosity.

\section{Ritual}

These data show how both societal and industry perception of the presumed right way to honor a deceased loved one changed between 1963 and 2009. The modern adaptation of traditional rituals, the manipulation of crosscultural practices, the creation of new rituals, and the individualization and personalization of existing rituals are all attempts by the funeral industry to capture social trends, regain dwindling profits, and ultimately, remain viable. The 
death rituals that were assumed to be necessary and appropriate in the early 1960s were dictated by a combination of tradition, religion and the presumed authority of the funeral director. The funeral process was considered a comprehensive and whole event, comprised of the usual time-honored steps. In this era, contributors to the journal encouraged their colleagues to offer "personalized" business, by way of a face-to-face visit to a family's home, a hand-written thank-you note following a transaction, or concession for a particular brand of coffee to be served in the parlor. Alteration of fundamental rituals was not addressed in the journal during this time because existing rituals were a tacit cultural presupposition. The topic was absent not because industry was avoiding it, but because the postmodern idea of adapting established social practices to specific tastes was not yet ubiquitous.

What becomes evident in just a few years, however, is that as amenability to consumer demands increased, so too did the industry's readiness to innovate. A 1970 contributor clearly recognizes the state of affairs, writing, "Our concept of offering service and merchandise based on what we think it should be is no longer acceptable. It means we must make available what people want-what they will buy!" ("The Image of Funeral Service" July/August 1970, italics original). Similar statements re-appear regularly in the journal from that year until the present. This new openness was in part due to the industry's recently uncertain social standing, attributable to the critique of author Jessica Mitford (and the ensuing backlash), and the new availability of corporate-based lower-cost alternatives. Beginning in the mid-seventies, the American funeral industry offered more and more 
progressive options for the commemoration of a death. A 1979 Mortuary

Management article describes the highly nontraditional rituals comprising the funeral of a Harley Davidson motorcycle club's vice-president ("Two Wheelers Pay Their Respects" April 1979). A decade later, a contributor reinforces the idea that traditional disposal rituals are becoming passé, urging his colleagues to "remember that young people today are not going to come up with the big bucks to petrify themselves and their families in small town U.S.A. Society doesn't work that way anymore" ("Funeral Homes and Their Perceptions and Realities" July/August 1990). In 2007, it is suggested that funeral directors approach their work "from the unexpected point of view. One idea is to ask yourself: 'What would happen if Walt Disney were in charge of my mortuary?"' ("Your Mortuary Success in 2007" May 2007). By 2009 the industry offers ideas for something more akin to a themed soiree, as seen in the following quotation from the website of the National Funeral Director's Association (NFDA):

As an example, an avid cowboy or cowgirl may want to ride off into the sunset one last time. Tasteful ways to honor their wish include:

- Using a covered wagon rather than a hearse

- Having their saddle and riding equipment displayed

- Playing western music

- Having their horse walk in the procession

- Having a barbecue after the service

What perhaps began as an amusing novelty became the norm. This trend of individualization did not at first necessarily affect the livelihood of funeral directors, but rather changed their occupation's description. In the past few years, 
however, organic new approaches have developed or re-emerged outside the realm of the established funeral industry, threatening to push the traditional funeral director into further obsolescence (e.g., home-based wakes, home burials, woodland burials). Technological advances have made death-related items much more accessible to the lay person. It is simple and straightforward, for example, for a consumer to purchase a casket online through www.walmart.com. In addition, the concept of audience-generated funerals has rapidly become widelyutilized. A 2005 Mortuary Management writer attempts to make a case for the necessity of a professional in such a format:

This concept takes the support of those who attend a memorial gathering, and allows those who know and care about the life being honored to participate. This sort of memorial occasion does not just happen. There must be an effective and supportive beginning and end. It takes a selfconfident leader like a funeral director to 'open' and 'close' this occasion effectively ("Audience-Generated Funerals, And More" March 2005).

A "meaningful" service has remained the funereal focus; what has evolved is the American understanding of the concept. In the perpetuation of modern death rituals, meaning is equated to creativity. Modernity strives for ritual and ceremony embedded in uniqueness. Individualizing one's own funeral or the funeral of a loved one has become the new norm. In the majority of cases, however, clients are choosing their unique "one-of-a-kind" memorial service from a industry-devised list of possible components. In other words, this supposed individualization is not truly individualized, but in most cases corporately molded (and can result in a funeral of rhetoric without true meaning). Once a burgeoning 
idea becomes adopted by the mainstream, and proceeds to be actually promulgated by the shapers of commerce as a legitimate trend, it is essentially stripped of its authenticity. Data indicate that new ways to memorialize "uniqueness" are now constantly being devised, marketed, discussed, and shaped by the image makers in the industry. For clients who prioritize uniqueness in both ritual and description, funeral homes are prepared to trademark themselves as a "Life Story Funeral Home," for example, "which is taking the growing trend of personalization to new heights, and more importantly, greater depths. Life Story Funerals...employ a team of professional writers to chronicle a person's life in rich detail. That story, together with personal family photos, is then told through printed materials, on the Web and in a compelling video, which is shown at the service" ("What's Your Story?" October 2006).

Consumerism goes hand in hand with the shaping of death rituals. The funeral industry, recognizing the consumer desire for personalization, is prepared to embrace and contribute to this "mass produced individualization." Schlosser (2002) notes that in the same way that "the centralized purchasing decisions of the large restaurant chains and their demands for standardized products have given a handful of corporations an unprecedented degree of power over the nation's food supply...the tremendous success of the fast food industry has encouraged other industries to adopt similar business methods (Schlosser 2002: 5)." In many ways, the industry has adopted this model and managed to effectively 'McDonaldize' death rituals. Among these analyzed articles, there is ample evidence of this movement within the American funeral service industry. 
It is a great paradox that modern individualized funeral services are hyperfocused on the unique contribution of one individual, yet there is rarely a palpable societal gap as a consequence of individual deaths. What seems to drive the modern choices we make about how our loved ones are remembered is a sense of their life as irreplaceable. Data indicate that these additional factors have had a significant impact on the way that death is recognized, internalized, signified, and mourned: what is currently popular and therefore attainable; what is affordable; what is reasonably do-able in the time allotted for preparation; and, what recent public memorial has pushed the envelope and opened the door for wider social acceptance of a different and new approach.

\section{Mode of Disposal}

Inarguably, one of the most significant developments in the comprehensive history of the funeral industry was the introduction and practice of modern embalming methods. Developed out of pure pragmatism and the necessity to make it possible for families of Civil War soldiers to identify their dead sons, embalming allowed families of the Civil War dead to participate in traditional $19^{\text {th }}$ century death rituals. Prior to the 1860 s, families prepared and presented deceased loved ones in their own homes, and the local pastor was understood to be the organizer of all related events. Embalming spawned the professionalization of funeral service, and consequently, spurred the creation of an entire death industry. 
In that era, the dead body was the focus of every ceremonial event associated with death. The corpse was the determining factor of what rituals were to be performed and when they would be undertaken. That norm prescribed clear social and cultural implications for the role of the family, the role of the funeral director, and the role of the mourner. Morticians came to operate under the belief that witnessing the corpse was a vital part of the process, and their role as a liaison between family and the embalming/cosmetology team came with a great responsibility to properly fulfill social expectations and subsequently ensure contentment. Psychology played a part in maintaining this tradition by emphasizing the ill emotional effects of foregoing or being denied the opportunity to view the dead body. In one of the first American studies of grief, psychiatrist Erich Lindemann touted viewing the corpse as the "active agent in the eventual triumph over death" (Laderman 2001: 117). The following quotes from the February 1978 issue of Mortuary Management precisely embody this sentiment:

We want her friends to have a chance to see her one last time, and I think it would be good for us to see her, too....

Brenda's father stopped me as I left the family in the chapel. 'You'll never know how much this has meant to us,' he said. 'We heard so many awful things about the wreck and, well, it's really helped... Laura looked very pretty. I feel a little better now - I think the wife does, too....

How easy it is to sometimes forget the important role the funeral director plays in guiding families like these back to the active world of the living. By side-stepping duties and failing to want to spend those extra hours with restorative work, a funeral director can leave a family with horrible thoughts of the suffering brought upon their loved one. And, too, they may never come face to face with the reality of the death that has occurred. But seeing their friend or loved one that one last time, relaxed and at rest, can bring peace of mind to some, reality to others. ...And when families like 
these say, 'Thank you for caring about our feelings,' you know you would have been making a tragic mistake by passing off a few hours' work on a closed casket ("One Last Time" February 1978).

These data suggest that emphasis on the significance of the corpse has by no means been wholly undermined; however, changes to this tradition have resulted in a much abbreviated viewing period or have eliminated it entirely. Most notably, a steady increase in the choice of cremation as mode of disposal has led to the popularization of death rituals with diminishing emphasis on what death looks like. As evidenced by treatment of the topic in Mortuary Management, the funeral industry's reaction to cremation bears an intriguing parallel to established stage theories of grief (i.e., denial, anger, bargaining, depression, acceptance). These data show a change in both stance and approach and reveal a significant evolution in perception, attitude, and activity with regards to the role of the corpse in American death rituals.

The industry has been unabashed in placing value judgments on those who chose or advocated for cremation. In January 1963, a Mortuary Management contributor writes, "Let's go way back. The heathens did cremate their leaders, but the Bible does not champion cremation, and the Talmud condemns it" ("The Past is Prologue" January 1963). Twenty years later, in 1983 another author reveals that, "For many in the industry, cremation is viewed as an inappropriate and ghastly evolution which many of us tend to ignore and refuse to recognize as being one of the most significant trends impacting our industry today" ( “Cremation...A Passing Phenomenon or Emerging Tradition?” June 1983). 
"Is It Time to Expose the Truth?" (April 1980) purports to be an exposé of the "unsavory" practice of cremation. The author of that article implies that if Americans truly knew what happened during the process, they would never subject their loved one to such unscrupulous procedures. He states, "Often times I have wondered why others that have had exposure to such [cremation] companies have not yelled out. And then again, I wonder if it really matters to some people... The untidy atmosphere, as well as the horrid odors, should be of concern to the health agency. No one seems too anxious or concerned about what's going on, or how." The author suggests that funeral directors aware of these practices expose direct-disposal firms, stating, "I only hope that the public soon becomes aware, and are not victims of something they may have had little opportunity to understand."

A May 1979 article cites the disposal choices available at the time: "traditional earth burial, crypt burial (in a structure called a mausoleum), or placement of cremated remains either in a columbarium niche or a lawn burial site" ("Questions and Answers: Evergreen-Washelli's Approach to Public Information" May 1979). In the subsequent decade, however, just as the industry may have begun feeling the slightest bit of comfort with the inclusion of cremation as a viable disposal option and a part of their repertoire of service offerings, social trends marched in yet more new ideas and approaches, some of which hold an even stronger threat of obsolescence for the mortician.

Accoutrement associated with and necessitated by this traditional centering on the body kept people employed in the businesses of casket 
manufacturing. Historically, the casket was a primary source of profit for the industry. As casket sales have dwindled, so have profits. A side effect of the decrease in demand was a steep increase in price: "The cost of ancillary goods and services-- the cemetery, burial vault, flowers, grave markers, monuments-- all have climbed dramatically." A cycle resulted where this new pricing structure unwittingly contributed to the demise of the corpse-focused traditional rituals. The article continues by matter-of-factly pointing out that "the traditional funeral is fast becoming out of reach for a large percentage of the population. So they choose another option: cremation" ("Funeral Homes and Their Perceptions and Realities" July/August 1990).

Funeral directors could no longer rely on that income and were forced to reduce overhead and consider ways to make up for the significant income loss. For some, becoming involved in the business of cremation was an obvious answer; for others, as indicated by many quotations in this journal, the idea was repugnant. The overarching feeling, however, was that like it or not, funeral homes that wanted to stay in business had no choice but to embrace cremation. Suggested in the early 1980s, and stated explicitly by the early 1990s, these data indicate that the reality of economics had trumped most anyone left in the industry still rejecting cremation on the basis of morality or sentimentality: "The choice of cremation, and the potential reevaluation of opportunities to serve cremation-minded clients, may be the savior of what is now known as traditional funeral service business. There are multitudes of options to present families in their request for cremation. These variables may be in conflict with funeral 
formalities and ultimate profitability. But it is our business to ensure satisfaction, and build on it" ("Burial, Cremation Shouldn't Affect Service, April 1993).

That said, the more notable finding is that although the articles acknowledge cremation and recognize its looming impact as early as 1980, there is a theme of persistent reminiscence and reassurance throughout the journal, even up until the most recent issues. The industry continues to feel the need to soothe itself, in some subtle ways and some ways quite explicitly, as evidenced by these quotes:

I honestly feel direct disposition, either cremation or burial, is psychologically unhealthy in most instances.... with direct disposition companies we know what they are selling the public. What they offer the consumer is minimum effort, virtually no service and usually the lowest prices. Consumers get exactly what they pay for. NOT MUCH!!! ("The Politics of Funeral Service" January 1995).

Cremation is an alternative to traditional earth burial. It is not necessarily what some practitioners view as the consumer's weapon against the rising cost of funerals. It's simply an alternative, just like the use of the competitor to perform services that one firm may refuse to offer ("Antiquated Thinking about Cremation" May 2000).

Years ago, cremation was seen and treated as simply a method of 'quick disposal,' done behind the scenes with no family involvement. If this is still your mindset, you need to change ("Swimming With the Tide of Cremation" July/August 2006).

Like it or not, your client-families are placing less and less importance on the physical body, and more importance on the person that once occupied it ("What's Your Story?" October 2006).

According to the National Funeral Directors Association, the cremation rate in the United States is expected to increase from 39 percent in 2010, and will 
exceed 58 percent by 2025 . As a negative correlation between the choice of cremation and industry profitability becomes increasingly real, the industry scrambles to reinvent itself. By 2009 , we find the industry actually suggesting elimination of the once highly lucrative casket-room walk-through. In "Technology and Trends in the Funeral Industry," the author writes that "walking through the showroom of caskets is a very uncomfortable experience for the family members" ("Technology and Trends in the Funeral Industry" June 2009). He advocates offering a web-based casket catalog as a substitute for the "uncomfortable experience" of seeing a room full of three-dimensional caskets. There are several implications here, not the least of which is industry awareness of the fact that casket-purchase is no longer the paramount event in the funeral home/client exchange. I would also suggest it is further a reflection on the conversion from corpse-focus to human-focus, from the dead to the living, an attempt at adaption to a death-denying society, and an indication of postmodern rejection of tradition.

\section{Matters of Image, Sustainability, and Commerce}

Throughout the studied period, articles maintain a steady focus on entrepreneurial matters. The trade press exists to provide current information on the state of affairs in an industry. That Mortuary Management does just that is hardly surprising or noteworthy. What is significant (and what these data seem to 
suggest) is that over time, the journal has shifted from a micro-level to a macrolevel focus. For example, earlier articles focus on the nuances of advertising, funeral home interior design, and "rolling stock." Later articles focus on sustainability, globalization, the economics of demand, threats to the industry, technology, psychology, and social trends. Articles increasingly hint at a macro approach as it becomes more obviously germane to the sociocultural setting. The industry adopted a larger-scale consciousness as consideration of the future became not a choice, but a necessity.

Realities of the business zeitgeist are continuously addressed. With its capacity to substantially impact the industry as whole, the launch of funeral corporate conglomerates garnered much attention since becoming household knowledge in the mid- to late 1960s. Initial industry reactions to the phenomenon convey a healthy trepidation, but a confident belief that the independent status quo will prevail. Leaders of long-standing family businesses that were successfully based on relationships and personalized service were appalled that they could be replaced by strangers in their communities. Article authors scoff at the notion of corporatizing a service so delicate. An author in 1983 writes:

Finally Americans are going to be treated to a scheme with a most novel approach. From the rolling hills of Tennessee comes word that an organization called United Dignity has incorporated to franchise funeral homes in at least twenty-two locations....Will the new franchise funeral homes be housed within urban and suburban shopping malls? Will our newest addition to the American way of death be an integral part of some well known fast food chain? Will this man attempt to meld funerals with the store-front lawyers, and the free health and dental clinics? Who knows where all of this could lead? ...Why, one might even see a funeral coach with stripes outfitted with a bell beckoning customers in a given 
neighborhood....And the good old established funeral directors who know what they're doing and why they're doing it, public and private alike, will go right on doing business as usual ("There Could Be a McDonald's in Funeral Service" January 1983).

Attitudes shift sharply as "old guard" funeral directors accepted the reality that not only were the corporate-owned homes not going away, they were quickly multiplying. The July/August 1984 issue contains an article entitled, "The Corporate World of Funeral Service...You Can Bet it's Here to Stay," in which the author clearly grasps and accepts the new order and actually admires the efficient corporate business model, stating: "SCI [Service Corporation International, a massive funeral business conglomerate]...is well-managed, wellfinanced, and certainly must be recognized as the corporation which brought new concepts of business and venture potential to the operations of mortuaries and their ancillary concerns."

Industry acceptance of corporatization is not yet widespread by 1988 , however. In that year (a full 24 years after the establishment of $\mathrm{SCI}$ ), journal contributors are still struggling with the transition to corporatized funerals, and commentary vacillates between irritation at those clinging to the past:

Corporate groups... are gobbling up the innards of what used to be a comfortable, family-oriented group of private enterprises. If there are still schools of thought in this industry that really believe that matters are going to change freeing funeral directors from the manacles of corporate intrusion, then those folks better look at their undergarment, for it is knotted around their ankles ("Change! It's a Different Marketplace Today..." October 1988). 
Corporate structures are indeed the strong new force of funeral service.

Independent funeral directors who use emotion to guide them instead of intellect to nurture progress, are going to find that time and events of today and tomorrow will leave them behind ("Change! It's a Different Marketplace Today...." October 1988).

\section{To indifference:}

Funeral corporations are no better, and no worse, than the rest of the remaining funeral folk. The people who run them do so for a profit, and they are not afraid to speak the word: 'PROFIT.' Independents, on the other hand, would have everyone believe that theirs alone is a labor of love; that money is an evil commodity that has never passed through their 'lily white hands' ("Funeral Homes and Their Perceptions and Realities" July/August 1990).

To backlash against the independents and full embrace of the corporate:

The traditionalists in funeral service, if that is the word, still seem to quake in their respective boots at the mere mention of the name Service Corporation International... Service Corporation International is spawning a revolution in funeral industry business and professional practices. And they are good at what they are doing....The Ma and $\mathrm{Pa}$ operators in funeral service are still an integral part of national mortuary operations. But those type of firms are diminishing and will continue to yield less influence in the private sectors of mortuary management in the future. That is why it behooves funeral directors today to take notice of corporations such as SCI ("The Corporate World of Funeral Service... You Can Bet It's Here to Stay" July/August 1984).

Public corporations are not perfect. Neither are independent funeral directors. One has only to go to the news section of any funeral publication to read about the failures in the latter group... If people in funeral service cannot live with themselves and solve their own problems, preferring to blame others for their dilemmas, then they threaten to seal themselves in their own caskets and vaults in a grave of despair...We better start facing ourselves and our own problems collectively. Then we can begin to enjoy a renaissance and put an end to the present inquisition ("Serious News or Silly Journalism" June 1992). 
An article published in 2001 suggests impending issues of greater significance than the advantages of corporate-owned vs. independently-owned funeral homes, asking: "What difference does it really make if the funeral director works for a corporate funeral home or an independent? Have we simply fabricated a mental barrier and fueled the fire to the point where most people believe the illusion?" ("The Independent Advantage is Not Guaranteed" March 2001). These data suggest that ultimately the question of ownership or source of authoritative decision-making is irrelevant; the much weightier question of "is the way we operate viable for future operations?" is the key dilemma.

In 1963, one year after the establishment of Service Corporation International, journalist Jessica Mitford released her impressions of the American funeral industry. Due in part to Mitford's contribution and lasting legacy, funeral directors never have been able to fully escape the stereotype of a greedy, unscrupulous, macabre money-grubber. Mitford's book, The American Way of Death, managed to gain considerable attention from the mainstream media and the public at large. The book sparked the beginning of the funeral industry's ongoing struggle with appearance and perception. The industry was forced to question its ego, its role in the designation of death services and the perpetuation of rituals, and its assumptions about client desires. Data analyzed in this study indicate that this evaluation of "presentation of self" did not happen immediately.

The industry's consideration of external social forces came only after an initial period of defensive reactions to Mitford's accusations and time spent scrambling to build a bulwark to safeguard its practices. By 1970 , however, an 
article entitled, "The Image of Funeral Service" indicates that the industry was reassessing its status and role. The author states: "FAMILY FIRST, and a word that you have been broadly exposed to recently, CONSUMERISM, are identical and analogous areas controlling our activities. Not only is this concept ALTRUISTIC, it is our only GUARANTEE of PERPETUITY!" ("The Image of Funeral Service" July/August 1970, emphases original). One of countless social movements of the late 1960's and early 1970's, consumer activism led to increased awareness of buyers' rights and resulted in government mandated reforms. This Mortuary Management author was an early convert to the idea that consumers would determine the future of the funeral industry.

By 1976 , the industry had graduated to a full-scale re-evaluation of the funeral service, its primary domain. In "Let's Not Take the Funeral for Granted", the author states, "To take the funeral for granted, as an unchanging ritual, is to misread the needs and interests of the American consumer" (March 1976). It appears that succumbing to this transition from proffering unquestioned expertise to being at the mercy of client fancies has required regular and continued prodding to the present day. Ranging from tales of ill-fated industries of the past: "Would not the railroad industry have been better served if it had been at least open-minded to the new alternative?" ("Cremation...A Passing Phenomenon or Emerging Tradition" June 1983); to brusque threats, "If we can provide facilities, services and products that are meaningful, and appropriately profitable to us, then we have a future in this service business. If we can't, or won't, it is time to give over to those who will" ("Burial, Cremation Shouldn't Affect Service, April 
1993); to boiled-down dictum, "Worthy of serious attention are the attitudes, requests and trends by clients" (“Burial, Cremation Shouldn't Affect Service, April 1993); to sensible assertions about the modern reality of the profusion of values and perspectives, "With the comingling of the GI generation, the Silent generation, the baby-boomer generation and now generation $\mathrm{X}$ and generation $\mathrm{Y}$, you create a challenging and mixed group of family members in which today's practitioner must confront and attempt to fulfill all their needs" ("Antiquated Thinking About Cremation" May 2000).

Today's funeral industry offers more services, products and ritual notions than at any other point in history, and more new alternatives are becoming available every day. These data suggest that the industry has been able to survive by developing a persistent focus on the pulse of American social and cultural tendencies (though there certainly have been casualties along the way). The funeral industry of 2009 is more of an expansive personality-preservation endeavor than a myopic corpse-preservation one. A formerly egocentric industrywide disposition has largely been replaced by one of realistic humility and submission to one of the outstanding tenets of postmodernity, diffuse and persistent change.

\section{Grief}

For most if its history, the American funeral industry myopically focused on the corpse; today, the emphasis is a comprehensive approach to the living, 
including pre-need and after-care services. Introductory sociology and psychology courses are compulsory in modern mortuary school curricula, along with classes entitled "Social Aspects of Death and Dying," "Pre-need" and "Psychology of Grief and Counseling Procedures." Elective options include "Death in Literature" and "Funeral Aftercare." Of course, these are all in conjunction with "Thanatochemistry" and "Cremation Fundamentals." Today's funeral director is expected to be an individual well-rounded in all ritual, biological, historical, spiritual, psychological, and social aspects of the death experience.

Preceding explicit mentions of grief support as a service offered by (or via) the funeral industry are allusions to pop grief psychology. In the articles selected for analysis, the first mention of industry-associated grief services does not occur until 1985. In April 1969, the journal included an article that was wholly different than any before it, "The Child and Death," in which the author addresses then-current psychological concepts related to death. Acknowledgement of any emotional aspects of mourning is absent from the journal in the six analyzed years preceding.

The inclusion of articles devoted to the emotional experience of grief echoes concurrent social psychological trends of humanism and existentialism. The industry's exposure to and acceptance of grief psychology has been nearly parallel to lay society's education on this topic. Elisabeth Kübler-Ross's $O n$ Death and Dying, which specifically introduced the stage theory concept of grieving, was published to great acclaim and widespread exposure in 1969. Reflecting the social and psychological zeitgeist spurred in part by Kübler-Ross's 
book, the aforementioned 1969 article, "The Child and Death" is

melodramatically written from the perspective of a child. The author writes,

"Instead of presenting a learned paper on the subject, 'The Child and Death', let

me attempt to allow the youngster to speak for himself....I will assume the role of a young man of 19 who in a developmental way is recalling his childhood and the traumatic experience of death...I am now the youngster, I speak to you- the adult world. Will you listen, really listen to what I have to say?" (The Child and Death" April 1969).

The aforementioned article could not have appeared prior to the mainstreaming of psychological concepts of self, growth and healing. Prior to widespread exposure and acceptance of these concepts, dealing with what happened after the funeral service was largely considered outside the realm of the industry. The emotional response to loss was not considered to be the domain of the funeral director. In fact, among the studied articles it was not considered at all. As with so many other changes the industry has grappled with and initially resisted, ignorance and disregard of the topic of grief is for the most part followed by acceptance. By 1985, the counseling of families is referenced as an expected and honorable component of the funeral director profession:

Explaining how grief works and how each person must grieve in his own way allows me to do more for the family than just conduct a funeral. Relying on past experiences I try to inform families of what feelings, problems or frustrations they have the potential of encountering during their period of readjustment. I don't have to worry about all the bad press funeral service takes when I know I have done everything possible to minimize the confusion and stress a family may encounter regarding the emotions they may feel and express ("All Things Considered, I'm Proud to Be a Funeral Director" May 1985). 
Likely mirroring a portion of his industry colleagues, however, a 1986

Mortuary Management contributor retains an old-school industry stance and

questions the market saturation of available grief services:

It seems that every hospital, health-care and social agency, hospice and do-good organization now have a wealth of professionals running around offering a complete spectrum of support groups for grief. In fact there are so many today, that it is tempting to say, "GOOD GRIEF," what's this all about? In the courses and seminars offered by most funeral organizations today there seems to be an inherent question of value received from these groups ("The Rivers of Change in Funeral Service...Can We Find Their Sources" July/August 1986, emphasis original).

This attitude is echoed by a different author five years later in 1991:

Now funeral organizations and their advertising agencies are having a new field day, cultivating the art of 'grief counseling'....the whole idea has gotten out of hand, though not before the funeral business decided to spend money advertising this new ware. It is sickening to listen to the sociological pablum that emanates from the 'therapists' or the 'counselors' now employed by professional funeral organizations, by funeral homes as staff and by a number of health care agencies. They propagate like rabbits in every community ("There are Hundreds of Trends but Only One Image" June 1991).

Demonstrating the widespread variation in industry attitudes toward funeral directors' new professional expectations, by 1995, a contributor considers himself to have sufficient expertise to comment on what is and is not psychologically healthy, stating: "I honestly feel direct disposition, either cremation or burial, is psychologically unhealthy in most instances" ("The Politics of Funeral Service" January 1995). 
Analyzed articles suggest that the industry's embrace of psychology has ultimately resulted in new business opportunities. Specifically, the role of music in grieving, pet loss support, and the promotion of web-based grief services have all led to expanded ventures. The following quotations serve as illustrative examples of recent industry upgrowth based on the incorporation of grief services:

Funeral directors- being counselors rather than order takers- should endeavor to suggest the use of music as much as possible because it can meet the heart needs of the family ("Silence Can Be Deathening" June 1995).

The death of a pet can be very traumatic for all the family members involved. Often downplayed, the grief one can endure as a result of these deaths can last for years. Many people feel that grieving over the death of an animal is irrational. Rationality has little to do with this phenomenon ("Pet Cemeteries Help Recognize Pet Bereavement" September 2000).

Client service does not end at the last shovel of dirt closing the grave. A number of the cemeteries offer some level of pet loss support....We are just now beginning to fully understand the impact of pet bereavement. As with all important losses, the bond between persons and their pets should be openly acknowledged and respected. We must broaden how society imposes and permits mourning. If the grief is deep, then people should be encouraged to mourn in appropriate ways. Pet cemeteries are helping to reenfranchise pet grief. The involvement of human cemetarians will help bring this transition about quicker by offering both ritual and recognition of a significant loss ("Pet Cemeteries Help Recognize Pet Bereavement" September 2000).

Also on the Internet, grief experts publish blogs and advise readers on how to grieve, heal and move forward ("Technology and Trends in the Funeral Industry" June 2009). 
Out of 92 articles in the 46 examined years of Mortuary Management, psychological and grief services are cited ten times. All citations are post-1985, with articles spaced approximately every two to three years. Although explicit mentions of the industry actually offering such a service does not occur until this latter part of the century, articles devoted to mourning and the psychological effects of grief begin to appear almost simultaneously with the publication and popular acceptance of On Death and Dying. These data indicate that the American funeral industry co-opted grief therapy both as way to remain suitably material to the modern psyche and as a logical next step in an increasingly nebulous future operating model. 


\section{CHAPTER V \\ CONCLUSION}

This study sought to identify ways the American funeral industry has evolved as evidenced by published trade journal articles. A review of 92 articles from the funeral industry trade journal Mortuary Management revealed significant changes in industry discourse from 1963-2009. The following six themes emerged through data analysis:

1) Industry preoccupation with continued social and cultural relevance through a steady rumination on change

2) Decreased ritual significance of religion

3) Coping.with a dismantling of traditional rituals; movement toward highly individualized rituals based on consumer demands

4) Normalization of cremation; movement away from the corpse as the most significant aspect of the ritual

5) Preoccupation with image maintenance, and social and economic sustainability

6) Acknowledgement and incorporation of grief services 
As proposed earlier, the journal's preoccupation with these thematic foci is a function of broad socio-cultural shifts from modernism to postmodern, and an associated obsession with perceived individual uniqueness and irreplaceability. Within the context of large-scale, or macro changes were three specific watershed events in the industry's history: 1) The 1962 development of Service Corporation International, and the subsequent corporatization of the funeral industry; 2) the 1963 publication of Jessica Mitford's American Way of Death, and the ensuing cultural backlash against the industry; and 3) the 1969 publication of Elisabeth Kübler-Ross' book On Death and Dying which popularized grief emotionality. (Not as culturally seminal, but very significant economically was the influence of Federal Trade Commission (FTC) investigations beginning in 1972, but not wholly enforced until 1984) (Torres 1988).

Considering cultural and regional differences, editorial influence, and any bias in interpretation, it is impossible to claim that the results of the present study illustrate a complete pan-American snapshot of the industry. However, attitudes notwithstanding, it is a fact that certain industry changes are taking place countrywide, and I posit that these changes are parallel to the wider social trend of post-modernization.

Because this is a trade journal, the editorial approach is necessarily based on implications for future earning possibilities. It is often a human reaction that no one should profit based on another's death or pain, so this approach might 
understandably be viewed as callous and reprehensible by the lay reader. It was critical to avoid such emotions; they are irrelevant in this consideration, as the journal is intended for persons directly involved in the enterprise of death and funerals.

There is a cavalier, almost egotistical attitude palpable in the earlier analyzed issues of Mortuary Management. Early article topics are lighthearted and mundane. Monumental change is not yet on the horizon. For example, historically, the American funeral home was decorated to imitate the parlors of home funerals past. And to be sure, a number of sixties-era articles in this content analysis cast a specific eye on the decoration of the establishments-- highlighting carpet piles and the effect of certain colors on the mood of patrons. Such detached blissful ignorance is short-lived, however.

What these data reveal is an industry struggling to remain relevant. It is looking to adapt, to reinvent, to continue not as the "dismal" trade, but develop into the celebratory trade. Numerous mentions of funeral planning as akin to the current hysteria that is wedding planning permeate the industry journals. There is a "do or die" sense of urgency palpable in the articles therein. In order to maintain a presence in contemporary American society, the funeral industry has already undergone massive restructuring. Branding and marketing changes have lent the industry an air of novelty, ready, willing and able to help you craft a service worthy of your loved one. 
We live in a society where elders regularly question nihilo sanctum estne? It is the type of thing that, with a "tsk-tsk," our mothers might say, "Back when I was young" and proceed to delve into a story depicting about "simpler" times. Wouters (2002:15) refers to the 1960s and 1970s as decades of collective "emancipation and informalization"; the effect of this wider cultural phenomenon is documented throughout the pages of Mortuary Management. As new generations embrace the postmodernist tendencies to look at the future as superior, rejecting the notion of history and tradition as sovereign, society is forced to innovate new ways to capture interest. Data indicate this is utterly true for the funeral industry. The "good old days" of the industry pre-date today's "paradox of choice." There is seemingly almost no aspect of the funeral industry that hasn't changed since 1963.

Rituals commemorating life and death are the most momentous of all the many emotional signifiers and place-keepers we utilize to observe events. It is staggering that the funeral industry and American attitudes have evolved to create completely new ways and means of acknowledging death that would be unrecognizable to our ancestors of only fifty years ago. As members of society have inarguably embraced Elias' (1991) notion of an "I-identity," the contemporary American response to death is increasingly characterized by innovation and personalization. This is evidenced by a transitioning funeral industry, evolving to match the postmodern death with equally postmodern opportunities for memorialization. The funeral, and thus, the entire industry of death, has become an avenue for declaration of a one-of-a-kind life. 
Operating under the notion that "he more personal and unique life is, the more it is irreplaceable," we have developed an obsession with singularization. As we are expected to imbue our lives with images and representations designed to our exact specifications, this discriminating society leaves us busily hyperfocused on ourselves and more aware than ever of our presentation of self. While supposedly promoting an increasingly global society, modern Western culture prizes individuality. Accordingly, memorialization no longer receives the communal blessing it did in bygone eras. Those decisions and practices "that were earlier predefined within the family association, the village community, or by recourse to the rules of social estates or classes, must now be perceived, interpreted, decided and processed by individuals themselves" (Beck and BeckGernsheim 2002:4).

Since the professionalization of the funeral industry, Americans have become ignorant as to how to take care of their dead. The immediate whisking away of the body at the moment of death, and the next exposure being the sterile, embalmed suited/dressed supine body, hands-folded, made up, hair washed, made the process seem 'magical' and beyond the reach of a 'lay' person. A recent reemergence of family controlled home burials indicates that, at least a small minority are beginning to explore old customs and simpler methods without the influence of experts. Whether this trend toward is one of the first indications of a reawakening of the understanding of the temporal nature of life, or just another way to express values is open for argument. 
Of course, rules and regulations exist for a reason. Though a home burial or green burial may sound rustic and idyllic to the postmodern do-it-yourselfer, it is easy to imagine a backlash as the next phase of change, possibly following some particularly disturbing story of corpse mishandling exploited by the media. A scenario is conceivable in which the media broadcast a particularly disturbing story of corpse mishandling, leading some to demand a return to the safe, protective confines of institutional control.

Historically, "love and fear" were the most powerful motivating factors for families organizing death and funeral rituals (Kastenbaum 2004). As the human population ever increases, modernity insists more than ever that we are important, and that life would go on differently without us. In truth, despite the sense of invincibility our postmodern science and technology-centric society tends to foster, humans are just as vulnerable as they have always been. Industrial age concerns of disease and ill manufacture have only been exchanged for terrorist attacks and hurricanes. Life is just differently precarious; it remains fragile as ever.

In our de-traditionalized world, Thomas Lynch (2004) refers to psychologists as the new clergy. These persons, he believes, are in the revered position formerly deigned to holy men, and as such, they have been granted the power to say that certain practices related to death, grief, and mourning are purposeful, efficient, and "psychologically correct." Modern education of psychotherapists and social workers prepared to work with the bereaved population serves to reinforce individualist grieving patterns. Bauman (1997) 
finds that the objective of current approaches to therapy has shifted from an attempt to aid clients in "finding themselves" to empowering clients to become what he terms "active choosers."

Mourners in America might be surprised to learn how industry and economics affect their traditional ways of mourning. In 1959, C.W. Mills wrote, "Seldom aware of the intricate connection between the patterns of their own lives and the course of world history, ordinary men do not usually know what this connection means for the kinds of men they are becoming and for the kinds of history-making in which they might take part" $(1959: 4)$. This is presently true as it applies to evolving death culture. Despite our best postmodern efforts to design our lives from a place of ingenuity, every fundamental part of our existence is intertwined with factors beyond our control. Unbeknownst to most in the throes of loss, the types of feelings we have, what exactly we are mourning, and how that loss is signified -- all of these things are products of the year, the country, the state, the city, the region, politics, the economy, the cost of gas, best-sellers; in a word, the zeitgeist. Mourning is not merely a manifestation of individual grief, but rather an amalgam of actions based on social cues, tradition, conformation, era, location and socioeconomic status. What seems to drive our contemporary choices is a desire for an interesting life and a unique legacy. As Bellah notes, "Where history and hope are forgotten and community means only the gathering of the similar, community degenerates into lifestyle enclave (Bellah, et al. 1985:154)". 
This analysis provides useful insight through utilization of an approach that has not yet previously been applied to research of the funeral industry. Despite a recent surge in popular media representation, including television, film, web-based media, daily newspaper, there continues to be a lack of published scholarly research focused on the funeral industry. The present study attempts to fill a gap by relying on raw data examined using a combined content and textual analysis approach.

There were, however, limitations in the design and methods approach. Accessibility constraints greatly inhibited the ease of the physical research collection necessary to perform this study. The only available complete collection of the entire publication output of the journal Mortuary Management is housed at the library of the National Funeral Director's Association in Wisconsin. This collection is not available for lending purposes, and other library holdings throughout the country are small and incomplete. Although I was able to utilize the collection housed by the Cincinnati College of Mortuary Science, the oldest available issue in that setting dates to 1963. The library's 1960s holdings are also largely irregular, causing adjustments in the random number assignment approach developed to designate analyzed issues. With less burdensome access to a comprehensive collection of all journal issues, this thesis could have expanded the sample size by increasing the number of articles analyzed per year, resulting in a broader and more illustrative picture of the funeral industry's evolution as indicated by Mortuary Management. 
The studied period of 1963-2009 explores only the recent history of the funeral industry. Brief anecdotal review of a sampling of Mortuary Management articles published in the decades spanning 1914-1959 indicated only minor changes in funeral industry procedures and conventions. Literature confirms that there were few critical industry shifts from the beginning to the middle of the twentieth century (Torres 1988). However, expanding the studied timeline to first date of publication (1914) would allow for analysis of the industry influencing capacity of relevant sociocultural occurrences such as the Great Depression, both world wars, the ubiquity of automobiles and television sets, and transitioning race relations.

Although authors were identified for every article, this study did not note changes in Mortuary Management editorship between the years 1963 and 2009. The significant influence of editorial authority on the inclusion and exclusion of journal content cannot be disregarded. It is possible that trends in identified thematic foci are evidence of occasional reassignment of the role of editor over time, reflecting the perspective and preferences of different individuals during occupation of the position.

As discussed, the content analysis instrument was developed in collaboration with an expert and underwent several stages of scrutiny and revision. Although the instrument was pre-tested by two individuals, increasing the number of tests could have led to a more fine-tuned tool intended to capture the most useful data points. Ultimately, the articles were analyzed and recorded by only this one author. More stringent inter-rater reliability tests, for example, 
assigning additional researchers the task of reading each article and completing each instrument, then comparing and contrasting the findings of all readers, could have further determined clarity of operational definitions validity of the protocol.

This study utilized both a quantitative content analysis approach and a qualitative textual analysis. By relying on a primarily qualitative approach to interpret the nuances of the data, it is possible that I have misinterpreted thematic implications. It is also possible that I have inadvertently left unaddressed significant phenomena affecting the funeral industry. Employing a solely quantitative methodology by adopting a more rigorous sampling approach and applying advanced statistical modeling would produce inarguable representation of variables exactly as they appear.

Reflection on these data also fosters several directions for future research. For example, replicating the current study though replacing Mortuary Management with one or more similar industry trade journals (e.g., The Director, American Funeral Director, American Cemetery) would provide supplementary findings and a basis of comparison for the data presented in this study. Replicating the current study with an alternate set of articles sampled from Mortuary Management could support and further augment these data.

During certain time periods in the publication history of Mortuary Management, articles were authored by just a handful of individuals, possibly reflecting the specific attitudes and personal beliefs of those particular few. 
Adding another voice of the discourse could confirm the findings of the current thesis, uncover additional data, or lead to new conclusions.

Another suggestion for a future approach would be augmenting data obtained through content and textual analysis. Increased coverage of the industry would be revealed through any combination of the following methods: inclusion of additional data sources such as direct observation of funeral rituals, interviews with industry professionals, enrollment in funeral education coursework, analysis of industry instructional manuals, total immersion as a funeral home employee, participation in grief support offerings, and administration of surveys or interview protocol with a random sample of lay citizens throughout the country.

Finally, isolating any one of the themes identified in this research and making it the focal point of a highly detailed analysis would result in richer data and highlight many of the subtle details doubtlessly omitted from a study with a more generalized approach. 


\section{REFERENCES}

Alat, Z. (2006). News coverage of violence against women: The Turkish case. Feminist Media Studies, 6(3), 295-314.

Archibold, R.C. (2009, July 8). At Jackson Memorial, Music and Mourning. The New York Times, pp. A14.

Archibold, R.C. (2009, September 4). In a Private Service, Last Goodbyes for Jackson. The New York Times, pp. A16.

Baglow, J.S. (2007). The rights of the corpse. Mortality, 12(3), 223-239.

Bauman, Z. (1997). Postmodernity and Its Discontents. New York: New York University Press.

Beck, U. and Beck-Gernsheim, E. (2002). Individualization. London; SAGE Publications.

Bedikian, Sonia A. (2008). The Death of Mourning: From Victorian Crepe to the Little Black Dress. Omega, 57(1) 35-52.

Bellah, R.N., et al. (1985). Habits of the Heart: Individualism and Commitment in American Life. Berkley, California: University of California Press.

Berger, A.A. (1998). Media Research Techniques: Second Edition. Thousand Oaks, California: SAGE Publications, Inc.

Black, L. (2009, July 29). Diamonds made of Michael Jackson's hair: Chicagoarea firm is making them. Chicago Tribune Archives.

Carverhill, P.A. (2002). Qualitative research in thanatology. Death Studies, 26, 195-207.

Clayden, A. \& Dixon, K. (2007). Woodland burial: Memorial arboretum versus natural native woodland? Mortality, 12(3), 240-260.

Cook, G. \& Walter, T. (2005). Rewritten rites: Language and social relations in traditional and contemporary funerals. Discourse \& Society, 16(3), 365391. 
Davies, D.J. (1997). Death, Ritual and Belief: The Rhetoric of Funerary Rites. London: Cassell.

Durkheim, E. [1912] (1995). The Elementary Forms of Religious Life, translated by Karen E. Fields. New York: Free Press.

Easterbrook, G. (2004). The Progress Paradox: How Life Gets Better While People Feel Worse. New York: Random House.

Eisenhandler, S.A. (2004). The arts of consolation: Commemoration and folkways of faith. Generations, 28(2), 37-40.

Elias, Norbert (1991) The Society of Individuals, edited by Michael Schröeter. Oxford: Blackwell.

Encyclopedia of Social Theory. (2006) Harrington, A., Muller, H.P., and Marshall, B.L. (Eds.). New York: Routledge.

Exley, C. (2004). Review article: The sociology of dying, death and bereavement. Sociology of Health \& Illness, 26(1), 110-122.

Ferguson, H. (2001). Social work, individualization and life politics. British Journal of Social Work, 31(1), 41-55.

Ferre', John P. "Last Words: Death and Public Self-Expression." Quoting God: How Media Shapes Ideas About Religion and Culture. Ed. Claire Badaracco. Baylor Universirre,ty Press, 2004. 129-142.

Ferre', John P. (2007). Animals Are People, Too: Pet Heaven in Popular Books. Horizons, 23-25.

Foltyn, J.L. (2008). The corpse in contemporary culture: identifying, transacting, and recoding the dead body in the twenty-first century. Mortality, 13(2), 99-104.

Fromm, E. (1966). Marx's Concept of Man. New York: Frederick Ungar Publishing Co.

Fowlkes, M.R. (1990). The social regulation of grief. Sociological Forum, 5(4), 635-652.

Garces-Foley, K. (2003). Funerals of the unaffiliated. Omega, 46(4), 287-302.

Garces-Foley, K. (2006). Death and Religion in a Changing World. Armonk, New York: M.E. Sharpe, Inc.

Glaser, G. (2009, April 19). The Funeral: Your Last Chance to Be a Big Spender. The New York Times, pp. BUl. 
Greenburg, J. \& Hier, S. (2009). CCTV Surveillance and the poverty of media discourse: A content analysis of Canadian newspaper coverage. Canadian Journal of Communication, 34, 461-486.

Guy C \& Tony, W. (2005). Rewritten rites: language and social relations in traditional and contemporary funerals. Discourse and Society, 16(3): 365391 .

Heflick, Nathan. (2005). Sentenced to Die: Last Statements and Dying on Death Row. Omega, 51(4), 323-336.

Hochschild, A. (1983). The Managed Heart. Berkeley; The University of California Press.

Howarth, G. \& Leaman, O. (2001). Encyclopedia of Death and Dying. New York: Routledge.

Hunter, E.G. (2008). Beyond death: Inheriting the past and giving to the future, transmitting the legacy of one's self. Omega, 56(4), 313-329.

Itzkoff, D. (2009, July 8). More Than 31 Million Viewers for Michael Jackson Memorial. New rYork Times.

Kastenbaum, R. (2004). Why funerals? Generations, 28(2), 5-10.

Kearl, M.C. (2004). Cremation: Desecration, purification, or convenience? Generations, 28(2), 15-20.

Kellaher, L., Prendergast, D., \& Hockey, J. (2005). In the shadow of the traditional grave. Mortality, 10(4), 237-250.

Kübler-Ross, Elisabeth. (1969). On Death and Dying. New York: Collier.

Laderman, G. (2003). Rest in Peace: A Cultural History of Death and the Funeral Home in Twentieth-Century America. New York: Oxford University Press.

Laderman, G. (1996). The Sacred Remains: American Attitudes Toward Death, 1799-1883. New Haven, Massachusetts: Yale University Press.

Lasch, C. (1978). The Culture of Narcissism: American Life in an Age of Diminishing Expectations. New York; W.W. Norton \& Company, Inc.

Lofland, L. (1985). The social shaping of emotion: the case of grief. Symbolic Interaction, 8(2), 171-190.

Lynch, T. (1997). The Undertaking: Life Studies from the Dismal Trade. London; Penguin Books. 
Lynch, T. (2004). Funerals-R-Us: From funeral home to mega-industry. Generations, 28(2), 11-14.

Marx, K., Engels, F. \& Tucker, R.C. (1978). The Marx-Engels Reader. New York: Norton.

Mitford, J. (1963). The American Way of Death. New York: Simon and Schuster.

Mills, C.W. (1959). The Sociological Imagination. New York; Oxford University Press.

Morris, C. (1972). The Discovery of the Individual 1050-1200. New York: Harper \& Row.

Musso, E. \& Wakefield, S.E.L. (2009). 'Tales of mind over cancer': Cancer risk and prevention in the Canadian print media. Health, Risk \& Society, 11(1), 17-38.

National Funeral Directors Association. Website. http://www.nfda.org/

Phillips, J.B. (2007). The changing presentation of death in the obituary, 18991999. Omega, 55(4), 325-346.

Raether, H.C. (1971). Successful Funeral Service Practice. Englewood Cliffs, New Jersey: Prentice-Hall, Inc.

Rosowsky, E. (2004). Doing your own funeral video. Generations, 28(2), 62-63.

Sanders, G. (2008). Themed death: novelty in the funeral industry. Consumers, Commodities \& Consumption, $10(1)$.

Schwartz, B. (2004). The Paradox of Choice: Why More is Less. New York: HarperCollins Publishers, Inc.

Schlosser, E. (2002). Fast Food Nation: The Dark Side of the All-American Meal. New York; Houghton Mifflin.

Shilling, Chris. (1993). The Body and Social Theory. London: SAGE

Publications.

Stanley, A. (2009, July 8). Funeral of a Superstar as a Media Moment. The New York Times, pp. A18.

The Sociology of Death: Theory, Culture, Practice. David Clark (Ed.). Oxford; Blackwell Publishers/The Sociological Review.

Thornton, M.C. (2009). Policing the borderlands: White and black American newspaper perceptions of multiracial heritage and the idea of race, 19962006. Journal of Social Issues, 65(1), 105-127. 
Torres, D.L. (1988). Professionalism, variation, and organizational survival. American Sociological Review, 53, 380-394.

Troyer, J. (2007). Embalmed vision. Mortality, 12(1), 22-47.

Turner, R. (1976). The real self: from institution to impulse. American Journal of Sociology, 81, 989-1016.

Turner, R. \& Gordon, S. (1981). The boundaries of the self: the relationship of authenticity in the self-conception, in Mervin D. Lynch, Ardyth A. NorenHebiesen and Kenneth J. Gergen (Eds.), Self-Concept: Advances in Theory and Research. Cambridge: Ballinger Publishing Co.

Walter, T. (1994). The Revival of Death. New York: Routledge.

Walter, T. (1996). A new model of grief: bereavement and biography. Mortality, $1(1), 7-25$.

Walter, T. (2001). From cathedral to supermarket: mourning, silence, and solidarity. Sociological Review, 49(4), 494-511.

Walter, T. (2005). Mediator deathwork. Death Studies, 29, 383-412.

Walter, T. (2005). Three ways to arrange a funeral: mortuary variation in the modern west. Mortality, 10(3), 173-192.

Winkel, H. (2001). A postmodern culture of grief? On individualization of mourning in Germany. Mortality, 6(1), 65-79.

Wouters, C. (2002). The quest for new rituals in dying and mourning: changes in the We-I balance. Body \& Society, 8(1), 1-27.

Yoo, G. (2001). Constructing deservingness: federal welfare reform, supplemental security income, and elderly immigrants. Journal of Aging and Social Policy, 13(4), 17-34.

Zezima, K. (2009, July 21). Home Burials Offer an Intimate Alternative. The New York Times, pp. Al. 


\section{APPENDIX A}

\section{LIST OF ANALYZED MORTUARY MANAGEMENT ARTICLES}

\begin{tabular}{|c|c|c|c|c|}
\hline Year & Month & Title & Author & Page(s) \\
\hline 1963 & November & $\begin{array}{l}\text { Outdoor Displays for } \\
\text { Religious Holidays }\end{array}$ & Unlisted & 22 \\
\hline 1963 & January & The Past is Prologue & W.M. Krieger & $26-27$ \\
\hline 1964 & September & $\begin{array}{l}\text { A Westerner Views } \\
\text { Education }\end{array}$ & $\begin{array}{l}\text { Dr. Hugh A } \\
\text { Tiner }\end{array}$ & $30-31$ \\
\hline 1964 & October & $\begin{array}{l}\text { NFDA Condemns Trade } \\
\text { Practice Rules }\end{array}$ & William Berg & $36-37$ \\
\hline 1965 & May & Your Filing System & Ernest W. Fair & 42,58 \\
\hline 1965 & July/August & $\begin{array}{l}\text { New Legislation on Pre- } \\
\text { Need Funds }\end{array}$ & Unlisted & 25 \\
\hline 1966 & March & $\begin{array}{l}\text { Success for the Opening } \\
\text { Requires Strategy }\end{array}$ & Unlisted & $12-17$ \\
\hline 1966 & June & Stopping the Promoter & $\begin{array}{l}\text { Albert J. } \\
\text { Meserow }\end{array}$ & $16-17,38$ \\
\hline 1967 & March & $\begin{array}{l}\text { Secrets of Motivating } \\
\text { People }\end{array}$ & Charles B. Roth & 30,53 \\
\hline 1967 & October & The National is Reborn & Unlisted & $19-20$ \\
\hline 1968 & September & $\begin{array}{l}\text { Secrets of Motivating } \\
\text { People }\end{array}$ & Charles B. Roth & 20,69 \\
\hline 1968 & February & $\begin{array}{l}\text { Essentials of Color } \\
\text { Coordination }\end{array}$ & Unlisted & $22-23$ \\
\hline 1969 & March & $\begin{array}{l}\text { The Future of Funeral } \\
\text { Service Education }\end{array}$ & $\begin{array}{l}\text { Karl O. } \\
\text { Heilmann }\end{array}$ & 22,46 \\
\hline 1969 & April & The Child and Death & $\begin{array}{l}\text { Dr. Earl A. } \\
\text { Grollman }\end{array}$ & $10-14$ \\
\hline 1970 & February & A Taxpayer's Briefing & Miram Miller & 14 \\
\hline 1970 & July/August & $\begin{array}{l}\text { The Image of Funeral } \\
\text { Service }\end{array}$ & $\begin{array}{l}\text { Richard A. } \\
\text { LaVigne }\end{array}$ & $12-13$ \\
\hline 1971 & February & $\begin{array}{l}\text { A Funeral Service } \\
\text { Investigation }\end{array}$ & Warren S. Bailey & $24-27$ \\
\hline 1971 & July/August & $\begin{array}{l}\text { Sell Yourself First: } \\
\text { Personalized Newspaper } \\
\text { Advertising }\end{array}$ & $\begin{array}{l}\text { Norman A. } \\
\text { Church }\end{array}$ & 12 \\
\hline 1972 & February & $\begin{array}{l}\text { Newspaper Ads That } \\
\text { Sell }\end{array}$ & $\begin{array}{l}\text { Norman A. } \\
\text { Church }\end{array}$ & $14-16$ \\
\hline 1972 & May & $\begin{array}{l}\text { Handling Lots of } \\
\text { Money? Keeping Too } \\
\text { Little of It? Where oh } \\
\text { Where? }\end{array}$ & Ernest W. Fair & $26-27$ \\
\hline 1973 & March & The Man from OSHA & Robert L. & $8-10$ \\
\hline
\end{tabular}




\begin{tabular}{|c|c|c|c|c|}
\hline & & & Kilburn & \\
\hline 1973 & September & $\begin{array}{l}\text { Funeral Economics } \\
\text { Tomorrow }\end{array}$ & Robert Ninker & $14-15$ \\
\hline 1974 & February & $\begin{array}{l}\text { Setting a Value for } \\
\text { Your Business }\end{array}$ & Joseph Arkin & $10-12$ \\
\hline 1974 & May & Automotive News & Unlisted & 32 \\
\hline 1975 & March & $\begin{array}{l}\text { Don't Provoke a Tough } \\
\text { Tax Audit }\end{array}$ & Joseph Arkin & $13-14$ \\
\hline 1975 & September & $\begin{array}{l}\text { The Sound of Silence: } \\
\text { Music for the Funeral }\end{array}$ & Merlyn Calvert & $20-21$ \\
\hline 1976 & March & $\begin{array}{l}\text { Let's Not Take the } \\
\text { Funeral for Granted }\end{array}$ & $\begin{array}{l}\text { Dr. Jay R. } \\
\text { Calhoun }\end{array}$ & $17-18$ \\
\hline 1976 & November & $\begin{array}{l}\text { How to Establish a } \\
\text { Value for Your } \\
\text { Business }\end{array}$ & Joseph Arkin & $21-23$ \\
\hline 1977 & June & Tragedy at Tenerife & Unlisted & $8-9$ \\
\hline 1977 & July/August & $\begin{array}{l}\text { Mr. Funeral Director, } \\
\text { Have You Gone to a } \\
\text { Funeral Lately? }\end{array}$ & Richard Myers & 7 \\
\hline 1978 & February & One Last Time & Randy Garner & $33-34$ \\
\hline 1978 & May & $\begin{array}{l}\text { Some Implications of } \\
\text { Chain Operations and } \\
\text { Investor Ownership of } \\
\text { Funeral Homes }\end{array}$ & $\begin{array}{l}\text { Ronald G.E. } \\
\text { Smith \& Gerard } \\
\text { L. Schoen }\end{array}$ & $21-23$ \\
\hline 1979 & April & $\begin{array}{l}\text { Two Wheelers Pay } \\
\text { Their Respects }\end{array}$ & Eddie Iwata & 37 \\
\hline 1979 & May & $\begin{array}{l}\text { Q\&A: Evergreen \& } \\
\text { Washelli's Approach to } \\
\text { Public Info }\end{array}$ & $\mathrm{N} / \mathrm{A} /$ & $32-35$ \\
\hline 1980 & April & $\begin{array}{l}\text { Is It Time to Expose the } \\
\text { Truth? }\end{array}$ & Robert Kilburn & 16 \\
\hline 1980 & October & $\begin{array}{l}\text { A Grand } \\
\text { Alliance...Forging for } \\
\text { the Future in Funeral } \\
\text { Service }\end{array}$ & Tom Fisher & 27 \\
\hline 1981 & June & $\begin{array}{l}\text { Catholic Church } \\
\text { Threatens to Enter } \\
\text { Denver Funeral } \\
\text { Business }\end{array}$ & Tom Fisher & $16-17,42$ \\
\hline 1981 & July/August & $\begin{array}{l}\text { Funeral Service Today: } \\
\text { The Economical } \\
\text { Apocalypse }\end{array}$ & Tom Fisher & $28-29,50$ \\
\hline 1983 & January & $\begin{array}{l}\text { There Could Be a } \\
\text { McDonald's in Funeral } \\
\text { Service }\end{array}$ & Tom Fisher & $18-19,47$ \\
\hline 1983 & June & $\begin{array}{l}\text { Cremation...A Passing } \\
\text { Phenomenon or } \\
\text { Emerging Tradition? }\end{array}$ & Terry Sousa & $22-23,50$ \\
\hline 1984 & January & $\begin{array}{l}\text { Another Funeral } \\
\text { Director Assaults the } \\
\text { Media or...Is Funeral } \\
\text { Service Assaulted by } \\
\text { the Media? }\end{array}$ & Tom Fisher & $20-21,38$ \\
\hline 1984 & July/August & $\begin{array}{l}\text { The Corporate World of } \\
\text { Funeral Service...You }\end{array}$ & Tom Fisher & $28-29,52$ \\
\hline
\end{tabular}




\begin{tabular}{|c|c|c|c|c|}
\hline & & $\begin{array}{l}\text { Can Bet it's Here to } \\
\text { Stay! }\end{array}$ & & \\
\hline 1985 & March & $\begin{array}{l}\text { American Funeral } \\
\text { Service is...Out in } \\
\text { Space! }\end{array}$ & Tom Fisher & $30-31$ \\
\hline 1985 & May & $\begin{array}{l}\text { All Things Considered, } \\
\text { I'm Proud to Be a } \\
\text { Funeral Director }\end{array}$ & Gregory Motzkin & $14-15$ \\
\hline 1986 & May & $\begin{array}{l}\text { The Trickle-Down } \\
\text { Syndrome and Funeral } \\
\text { Service }\end{array}$ & Tom Fisher & $16-17$ \\
\hline 1986 & July/August & $\begin{array}{l}\text { The Rivers of Change in } \\
\text { Funeral Service...Can } \\
\text { We Find Their Sources? }\end{array}$ & Tom Fisher & $19-21$ \\
\hline 1987 & February & FTC Survey and You & Gary Larson & $14-15$ \\
\hline 1987 & May & $\begin{array}{l}\text { The Merger of Service } \\
\text { Corporation } \\
\text { International and } \\
\text { AMEDCO }\end{array}$ & Unlisted & $14-15$ \\
\hline 1988 & July/August & $\begin{array}{l}\text { A Mid-Summer } \\
\text { Potpourri of American } \\
\text { Funeral Service }\end{array}$ & Tom Fisher & 10 \\
\hline 1988 & October & $\begin{array}{l}\text { Change! It's a Different } \\
\text { Marketplace Today... }\end{array}$ & Tom Fisher & $12-15$ \\
\hline 1989 & October & A Lesson in Caring & Steven Palmer & 16 \\
\hline 1989 & March & $\begin{array}{l}\text { Communication With } \\
\text { Parents for the Sake of } \\
\text { the Children }\end{array}$ & L. Wayne Harris & $20-21$ \\
\hline 1990 & June & $\begin{array}{l}\text { The Viral Epidemic } \\
\text { Sweeping Funeral } \\
\text { Service- It's Called } \\
\text { L.O.G.P. }\end{array}$ & Tom Fisher & $14-17$ \\
\hline 1990 & July/August & $\begin{array}{l}\text { Funeral Homes and } \\
\text { Their "Perceptions and } \\
\text { Realities" }\end{array}$ & Tom Fisher & $12-15$ \\
\hline 1991 & June & $\begin{array}{l}\text { There are Hundreds of } \\
\text { Trends But Only One } \\
\text { Image }\end{array}$ & Tom Fisher & $9-11$ \\
\hline 1991 & October & $\begin{array}{l}\text { Your Preneed } \\
\text { Inventory- Three } \\
\text { Informed but Different } \\
\text { Views }\end{array}$ & H. Benton & $14-15$ \\
\hline 1992 & June & $\begin{array}{l}\text { Serious News or Silly } \\
\text { Journalism? }\end{array}$ & Tom Fisher & $12-14$ \\
\hline 1992 & July/August & $\begin{array}{l}\text { Third Party Sellers: } \\
\text { Distracting Mosquitoes } \\
\text { in the Funeral } \\
\text { Marketplace! }\end{array}$ & Tom Fisher & $18-20$ \\
\hline 1993 & April & $\begin{array}{l}\text { Burial, Cremation- } \\
\text { Shouldn't Affect } \\
\text { Service }\end{array}$ & Ron Hast & 6,25 \\
\hline 1993 & June & Employees on Call & $\begin{array}{l}\text { Douglas O. } \\
\text { Meyer }\end{array}$ & 19 \\
\hline 1994 & July/August & $\begin{array}{l}\text { Summary and } \\
\text { Discussion of Changes }\end{array}$ & $\begin{array}{l}\text { Douglas O. } \\
\text { Meyer }\end{array}$ & $12-13$ \\
\hline
\end{tabular}




\begin{tabular}{|c|c|c|c|c|}
\hline & & to the FTC Rule & & \\
\hline 1994 & November & $\begin{array}{l}\text { Fast Foods, Microwaves } \\
\& \text { Funeral Service }\end{array}$ & Gregory Motzkin & $14-15$ \\
\hline 1995 & June & $\begin{array}{l}\text { Silence Can Be } \\
\text { Deathening }\end{array}$ & $\begin{array}{l}\text { Merrill P. } \\
\text { Womach }\end{array}$ & 16-19 \\
\hline 1995 & January & $\begin{array}{l}\text { The Politics of Funeral } \\
\text { Service }\end{array}$ & $\begin{array}{l}\text { Gregory } \\
\text { Motzkin }\end{array}$ & $18-19$ \\
\hline 1996 & June & $\begin{array}{l}\text { The Quality of Quality } \\
\text { Isn't What it Used to Be }\end{array}$ & Tom Fisher & $10-13$ \\
\hline 1996 & July/August & $\begin{array}{l}\text { The Happy Hunting } \\
\text { Grounds }\end{array}$ & Jerry J. Brown & $16-17$ \\
\hline 1997 & January & $\begin{array}{l}\text { Why a Trade Show for } \\
\text { the Funeral Industry? }\end{array}$ & $\begin{array}{l}\text { Robert J. } \\
\text { Moellman }\end{array}$ & $14-16$ \\
\hline 1997 & April & One Size Fits All & $\begin{array}{l}\text { David J. } \\
\text { Walkinshaw }\end{array}$ & $20-21$ \\
\hline 1998 & May & $\begin{array}{l}\text { Should the Past Become } \\
\text { Prologue? }\end{array}$ & Jerry Brown & 17 \\
\hline 1998 & December & Changing Attitudes & Denise Moriarty & $20-21$ \\
\hline 1999 & July/August & Denver Tragedy & John J. Horan & $14-16$ \\
\hline 1999 & December & Echoes of Gettysburg & Jerry Brown & $17-18$ \\
\hline 2000 & September & $\begin{array}{l}\text { Pet Cemeteries Help } \\
\text { Recognize Pet } \\
\text { Bereavement }\end{array}$ & $\begin{array}{l}\text { James H. } \\
\text { Gadberry }\end{array}$ & $18-19$ \\
\hline 2000 & May & $\begin{array}{l}\text { Antiquated Thinking } \\
\text { About Cremation }\end{array}$ & Fred H. Kitchen & $14-15$ \\
\hline 2001 & September & $\begin{array}{l}\text { Houston, You Have a } \\
\text { Problem. Willie's } \\
\text { Coming to Town }\end{array}$ & Sue Simon & $12-13$ \\
\hline 2001 & March & $\begin{array}{l}\text { The Independent } \\
\text { Advantage is Not } \\
\text { Guaranteed }\end{array}$ & Fred H. Kitchen & $10-12$ \\
\hline 2002 & March & $\begin{array}{l}\text { If Necessity is the } \\
\text { Mother of Invention, } \\
\text { Beware the Unitarians }\end{array}$ & Sue Simon & $9-10$ \\
\hline 2002 & May & A Cowboy's Funeral & Jerry J. Brown & $8-9$ \\
\hline 2003 & July/August & $\begin{array}{l}\text { Why Does Blue Paint } \\
\text { Cost More Than Gray? }\end{array}$ & $\begin{array}{l}\text { Beacham } \\
\text { McDougald }\end{array}$ & $14-15$ \\
\hline 2003 & September & $\begin{array}{l}\text { First Lewis \& Clark, } \\
\text { Then NFDA }\end{array}$ & Jerry J. Brown & 14 \\
\hline 2004 & June & $\begin{array}{l}\text { When Communities } \\
\text { Beg for More Public } \\
\text { Space }\end{array}$ & $\mathrm{N} / \mathrm{A}$ & 15 \\
\hline 2004 & July/August & $\begin{array}{l}\text { Selling, Renting, } \\
\text { Buying, and Donating } \\
\text { Bodies }\end{array}$ & Ron Hast & $4-6$ \\
\hline 2005 & March & $\begin{array}{l}\text { Audience Generated } \\
\text { Funerals and More }\end{array}$ & Ron Hast & 4 \\
\hline 2005 & September & $\begin{array}{l}\text { Reverence and } \\
\text { Sensitivity are Their } \\
\text { Creed }\end{array}$ & Joe Adelizzi & $24-25$ \\
\hline 2006 & July/August & $\begin{array}{l}\text { Swimming With the } \\
\text { Tide of Cremation }\end{array}$ & $\begin{array}{l}\text { Douglas } O . \\
\text { Meyer }\end{array}$ & 14 \\
\hline 2006 & July/August & $\begin{array}{l}\text { Sensitivity: A Must for } \\
\text { Better Business }\end{array}$ & $\begin{array}{l}\text { Gloria } \\
\text { Lintermans \& } \\
\text { Marilyn }\end{array}$ & $20-21$ \\
\hline
\end{tabular}




\begin{tabular}{|l|l|l|l|l|}
\hline & & & Stolzman & \\
\hline 2007 & May & $\begin{array}{l}\text { Your Mortuary Success } \\
\text { in 2007 }\end{array}$ & Brian J. Porteous & $16-17$ \\
\hline 2007 & July/August & $\begin{array}{l}\text { MySpace and } \\
\text { Facebook: Online } \\
\text { Memorials for the Next } \\
\text { Generation }\end{array}$ & Robin Heppell & $16-17$ \\
\hline 2008 & June & Weddings and Funerals & Barbara A. Koch & 16 \\
\hline 2008 & January & $\begin{array}{l}\text { Flowers are Love's } \\
\text { Truest Language }\end{array}$ & Kim Stacey & $34-37$ \\
\hline 2009 & April & $\begin{array}{l}\text { Funeral Home Design } \\
\text { and Maintenance }\end{array}$ & John Gary & $20-22$ \\
\hline 2009 & June & $\begin{array}{l}\text { Technology and Trends } \\
\text { in the Funeral Industry }\end{array}$ & Louise Zweben & $16-17$ \\
\hline
\end{tabular}




\section{APPENDIX B}

\section{CONTENT ANALYSIS INSTRUMENT}

Date: Title: Author:

Tone: neutral — stubborn - open-minded - threatened - threatening — confident

Does the article encourage an attitude more accepting of change? Yes No

Does the article encourage, either directly or indirectly, the possibility of doing things

differently (behaviorally speaking) than they are currently done? Yes No

\section{Does the article address.... If yes....

YES NO POSITIVE NEGATIVE NEUTRAL

Tradition?

Change?

Religion?

Secular approach?

Cremation?

Embalming/corpse preparation?

Alternatives to traditional rituals?

Physical business matters (e.g., décor, autos)?

Ritual particulars?

Industry image?

Consumer wants/demand economics?

A new idea or practice?

A new product?

Industry sustainability?

Corporate practices/takeover?

Psychological/grief services?

Personalization of industry services?

Individualization of death rituals?

\section{Attitudes and values conveyed?}

Quotes of interest: 


\section{CURRICULUM VITAE}

NAME:

ADDRESS:

DOB:

EDUCATION

\& TRAINING
Lisa Suzanne Crabtree

1213 Ellison Avenue

Louisville, Kentucky 40204

Louisville, Kentucky - October 19, 1980

B.A., English and Psychology

Bellarmine University

1999-2003 